\title{
Clinical implementation of RNA sequencing for Mendelian disease diagnostics
}

Vicente A. Yépez ${ }^{1,2, \dagger}$, Mirjana Gusic ${ }^{1,4,5, \dagger}$, Robert Kopajtich ${ }^{1,4}$, Christian Mertes ${ }^{2}$, Nicholas H. Smith $^{2}$, Charlotte L. Alston ${ }^{6,7}$, Rui Ban ${ }^{4,8}$, Skadi Beblo ${ }^{9}$, Riccardo Berutti ${ }^{1,4}$, Holger Blessing ${ }^{10}$, Elżbieta Ciara $^{11}$, Felix Distelmaier ${ }^{12}$, Peter Freisinger ${ }^{13}$, Johannes Häberle ${ }^{14}$, Susan J. Hayflick ${ }^{15}$, Maja Hempel ${ }^{16}$, Yulia S. Itkis ${ }^{17}$, Yoshihito Kishita ${ }^{18,19}$, Thomas Klopstock ${ }^{20,21,22}$, Tatiana D. Krylova $^{17}$, Costanza Lamperti ${ }^{23}$, Dominic Lenz ${ }^{24}$, Christine C. Makowski ${ }^{25}$, Signe Mosegaard ${ }^{26}$, Michaela F. Müller ${ }^{2}$, Gerard Muñoz-Pujol ${ }^{27}$, Agnieszka Nadel ${ }^{1,4}$, Akira Ohtake ${ }^{28,29}$, Yasushi Okazaki $^{18}$, Elena Procopio ${ }^{30}$, Thomas Schwarzmayr ${ }^{1,4}$, Joél Smet ${ }^{31}$, Christian Staufner ${ }^{24}$, Sarah L. Stenton $^{1,4}$, Tim M. Strom ${ }^{1,4}$, Caterina Terrile ${ }^{4}$, Frederic Tort ${ }^{27}$, Rudy Van Coster ${ }^{31}$, Arnaud Vanlander $^{31}$, Matias Wagner ${ }^{1,4}$, Manting $\mathrm{Xu}^{4,8}$, Fang Fang ${ }^{8}$, Daniele Ghezzi ${ }^{23,32}$, Johannes A. Mayr $^{33}$, Dorota Piekutowska-Abramczuk ${ }^{10}$, Antonia Ribes ${ }^{26}$, Agnès Rötig ${ }^{34}$, Robert W. Taylor ${ }^{6,7}$, Saskia B. Wortmann ${ }^{1,4,22,35}$, Kei Murayama ${ }^{36}$, Thomas Meitinger ${ }^{1,4}$, Julien Gagneur ${ }^{1,2,37, *}$, Holger Prokisch $^{1,4,8, *}$

\section{Affiliations:}

1. Institute of Human Genetics, School of Medicine, Technical University of Munich, Munich, Germany

2. Department of Informatics, Technical University of Munich, Garching, Germany

3. Quantitative Biosciences Munich, Department of Biochemistry, Ludwig-Maximilians-Universität, Munich, Germany

4. Institute of Human Genetics, Helmholtz Zentrum München, Neuherberg, Germany

5. DZHK (German Centre for Cardiovascular Research), partner site Munich Heart Alliance, Munich, Germany

6. Wellcome Centre for Mitochondrial Research, Translational and Clinical Research Institute, Faculty of Medical Sciences, Newcastle University, Newcastle upon Tyne, NE2 4HH, United Kingdom

7. NHS Highly Specialised Services for Rare Mitochondrial Disorders, Royal Victoria Infirmary, Newcastle upon Tyne Hospitals NHS Foundation Trust, Queen Victoria Road, Newcastle upon Tyne, NE1 4LP, UK

8. Department of Pediatric Neurology, Beijing Children's Hospital, Capital Medical University, National Center for Children's Health, Beijing, China

9. Department of Women and Child Health, Hospital for Children and Adolescents, Center for Pediatric Research Leipzig (CPL), University Hospitals, University of Leipzig, Leipzig, Germany

10. Department for Inborn Metabolic Diseases, Children's and Adolescents' Hospital, University of Erlangen-Nürnberg, Erlangen, Germany

11. Department of Medical Genetics, Children's Memorial Health Institute, Warsaw, Poland

12. Department of General Pediatrics, Neonatology and Pediatric Cardiology, Heinrich-

Heine-University, Düsseldorf, Germany

13. Department of Pediatrics, Klinikum Reutlingen, Reutlingen, Germany

14. University Children's Hospital Zurich and Children's Research Centre, Zürich, Switzerland

15. Department of Molecular and Medical Genetics, Oregon Health \& Science University, Portland, USA

16. Institute of Human Genetics, University Medical Center Hamburg-Eppendorf,

Hamburg, Germany

17. Department of Inborn Errors of Metabolism, FSBI 'Research Centre for Medical Genetics', Moscow, Russia

18. Diagnostics and Therapeutics of Intractable Diseases, Intractable Disease Research Center, Juntendo University, Graduate School of Medicine, Japan

19. Department of Life Science, Faculty of Science and Engineering, Kindai University, Osaka, Japan 
medRxiv preprint doi: https://doi.org/10.1101/2021.04.01.21254633; this version posted May 16, 2021. The copyright holder for this preprint (which was not certified by peer review) is the author/funder, who has granted medRxiv a license to display the preprint in perpetuity.

It is made available under a CC-BY-NC-ND 4.0 International license .

20. Department of Neurology, Friedrich-Baur-Institute, University Hospital, Ludwig-Maximilians-Universität, Munich, Germany

21. German Center for Neurodegenerative Diseases (DZNE), Munich, Germany

22. Munich Cluster for Systems Neurology (SyNergy), Munich, Germany

23. Unit of Medical Genetics and Neurogenetics, Fondazione IRCCS (Istituto di Ricovero e Cura a Carattere Scientifico) Istituto Neurologico Carlo Besta, Milan, Italy

24. Division of Neuropediatrics and Pediatric Metabolic Medicine, Center for Pediatric and Adolescent Medicine, University Hospital Heidelberg, Heidelberg, Germany

25. Department of Pediatrics, Technical University of Munich, Munich, Germany

26. Research Unit for Molecular Medicine, Department of Clinical Medicine, Aarhus University, Aarhus, Denmark

27. Section of Inborn Errors of Metabolism-IBC, Department of Biochemistry and Molecular Genetics, Hospital Clínic, IDIBAPS, CIBERER, Barcelona, Spain

28. Department of Pediatrics \& Clinical Genomics, Faculty of Medicine, Saitama Medical University, Saitama, Japan

29. Center for Intractable Diseases, Saitama Medical University Hospital, Saitama, Japan

30. Inborn Metabolic and Muscular Disorders Unit, Anna Meyer Children Hospital, Florence, Italy

31. Department of Pediatric Neurology and Metabolism, Ghent University Hospital, Ghent, Belgium

32. Department of Pediatrics, Paracelsus Medical University Salzburg, Salzburg, Austria

33. Department of Pathophysiology and Transplantation, University of Milan, Milan, Italy

34. Université de Paris, Institut Imagine, INSERM UMR 1163, Paris, France

35. Amalia Children's Hospital, Radboudumc Nijmegen, Nijmegen, The Netherlands

36. Department of Metabolism, Chiba Children's Hospital, Chiba, Japan

37. Institute of Computational Biology, Helmholtz Zentrum München, Neuherberg, Germany

$\dagger$ Contributed equally to this work

* Corresponding authors: gagneur@in.tum.de, prokisch@helmholtz-muenchen.de

Keywords: RNA-seq, genetic diagnostics, Mendelian diseases

One sentence summary: Implementation of RNA-seq as a complementary tool in standard diagnostics achieves a $16 \%$ in diagnosis rate over whole exome sequencing.

\begin{abstract}
Background: Lack of functional evidence hampers variant interpretation, leaving a large proportion of cases with a suspected Mendelian disorder without genetic diagnosis after genome or whole exome sequencing (WES). Research studies advocate to further sequence transcriptomes to directly and systematically probe gene expression defects. However, collection of additional biopsies, and establishment of lab workflows, analytical pipelines, and defined concepts in clinical interpretation of aberrant gene expression are still needed for adopting
\end{abstract}


medRxiv preprint doi: https://doi.org/10.1101/2021.04.01.21254633; this version posted May 16, 2021. The copyright holder for this preprint (which was not certified by peer review) is the author/funder, who has granted medRxiv a license to display the preprint in perpetuity.

It is made available under a CC-BY-NC-ND 4.0 International license .

RNA-sequencing (RNA-seq) in routine diagnostics.

Methods: We implemented an automated RNA-seq protocol and a computational workflow with which we analyzed skin fibroblasts of 303 individuals with a suspected mitochondrial disease which previously underwent WES.

Results: We detected on average 12,500 genes per sample including around $60 \%$ disease genes a coverage substantially higher than with whole blood, supporting the use of skin biopsies. We prioritized genes demonstrating aberrant expression, aberrant splicing, or mono-allelic expression. The pipeline required less than one week from sample preparation to result reporting and provided a median of eight disease-associated genes per patient for inspection. A genetic diagnosis was established for $16 \%$ of the 205 WES-inconclusive cases. Detection of aberrant expression was a major contributor to diagnosis including instances of $50 \%$ reduction, which, together with mono-allelic expression, allowed for the diagnosis of dominant disorders caused by haploinsufficiency. Moreover, calling aberrant splicing and variants from RNA-seq data enabled detecting and validating splice-disrupting variants, of which the majority fell outside WES-covered regions.

Conclusion: Together, these results show that streamlined experimental and computational processes can accelerate the implementation of RNA-seq in routine diagnostics.

\section{Background}

It is estimated that at least $3.5-6 \%$ of the human population is affected by a rare disease (1), of which presumably $\sim 80 \%$ have a genetic cause (2). Although not necessarily providing the cure, establishing the correct and timely diagnosis of a Mendelian disease can improve disease 
medRxiv preprint doi: https://doi.org/10.1101/2021.04.01.21254633; this version posted May 16, 2021. The copyright holder for this preprint (which was not certified by peer review) is the author/funder, who has granted medRxiv a license to display the preprint in perpetuity. It is made available under a CC-BY-NC-ND 4.0 International license .

management, provide prognostic information, and inform genetic counselling (3-5). Clinical implementation of next generation sequencing (NGS), especially whole exome sequencing (WES), revolutionized genetic diagnostics of individuals suspected of having a Medelian disorder by improving diagnostic yield and accelerating discovery of novel disease genes $(6,7)$. Nevertheless, the diagnostic yield of WES analysis rarely exceeds $50 \%$ and hence leaves the majority of patients without a genetic diagnosis (8-12). Inconclusive WES can be partially attributed to the challenges concerning variant detection, prioritization, and interpretation. Although whole genome sequencing (WGS) allows, in principle, the detection of all genomic variants, its clinical implementation has reported similar diagnostic rates to those of WES $(13,14)$. This indicates that variant prioritization and interpretation are the main challenges in genetic diagnostics (15).

So far, variants predicted to have potentially large effects on protein function are limited to large copy number variations, loss-of-function variants such as frameshift, start loss, stop gain, and stop loss, and variants altering splice acceptor or donor dinucleotides (16). However, it has been suggested that up to $30 \%$ of pathogenic variants fall within non-coding regions $(17,18)$. Moreover, multiplex splicing assays showed that splicing-disturbing variants include about 10\% of pathogenic exonic variants and are difficult to predict $(19,20)$. Although many in silico tools have been developed to predict the effect of a variant on transcription, splicing, or RNA stability, their accuracy remains too low to establish a firm diagnosis. Without the necessary functional validation using either a minigene or patient biopsy material, splice-region and non-coding variants remain variants of uncertain significance (VUS, (21)). 
medRxiv preprint doi: https://doi.org/10.1101/2021.04.01.21254633; this version posted May 16, 2021. The copyright holder for this preprint (which was not certified by peer review) is the author/funder, who has granted medRxiv a license to display the preprint in perpetuity. It is made available under a CC-BY-NC-ND 4.0 International license .

By directly probing transcript abundance and sequence on a transcriptome-wide basis, RNA-seq allows systematic identification of aberrant transcript events, defined as genes expressed at aberrant levels, aberrantly spliced genes, and mono-allelically expressed (MAE) rare variants. Detection of such events enables validation of VUS potentially affecting the transcript, re-interpretation of VUS when linked to an aberrant transcript event, and discovery of pathogenic variants not covered by WES. A recent study concluded that up to $31 \%$ splicing VUSs could reach either a likely pathogenic or likely benign classification from RNA-seq analysis (22). The application of RNA-seq has increased diagnostic rates by $8-36 \%$ across a variety of rare disorders and selected cohorts of up to approximately one hundred affected individuals (23-28). Besides increasing the diagnostic yield, RNA-seq can improve the understanding of the molecular pathomechanism of the variant and basic genetic mechanisms. This can also be of therapeutic importance, for instance, to design splicing-targeted treatments, as has been demonstrated for example in Duchenne muscular dystrophy (29). While these initial studies are promising, routine clinical implementation of RNA-seq requires robust and efficient computational workflows, establishment of quality controls, and adequate RNA source material.

Here, we report on our experience on the implementation of RNA-seq into clinical diagnostics using patient-derived skin fibroblasts (Fig. 1). We demonstrate the application of our validated computational workflow, DROP (30), which integrates preprocessing and quality control steps, as well as modules for detecting aberrant expression, aberrant splicing, and MAE (Fig. 1), and to which we have added a new module for RNA-seq based variant calling. We apply this workflow to a compendium of WES and RNA-seq samples of 303 individuals suspected of having a mitochondrial or other Mendelian disease, the largest such dataset to date. For each type 
medRxiv preprint doi: https://doi.org/10.1101/2021.04.01.21254633; this version posted May 16, 2021. The copyright holder for this preprint (which was not certified by peer review) is the author/funder, who has granted medRxiv a license to display the preprint in perpetuity.

It is made available under a CC-BY-NC-ND 4.0 International license .

of aberrant event, we examine their genetic background and provide diagnostic guidance through case studies. While our analysis is based solely on fibroblast-derived material and with the majority of individuals suspected of having a mitochondrial disorder, our study also addresses the value of other clinically-accessible tissues for the diagnosis of Mendelian disorders.

\section{Results}

RNA-seq analysis workflow

Extending the study of Kremer and colleagues (23) to support routine diagnostic testing, we recruited 303 individuals suspected to be affected by a Mendelian disorder with fibroblasts cell lines available within an international collaboration, and performed WES and RNA-seq on them (table S1, fig. S1, Materials and Methods). Almost all individuals (87\%, 263 out of 303) were clinically suspected to suffer from a mitochondrial disease, presenting with a broad spectrum of clinical signs and symptoms. Mitochondrial disease represents an attractive class of rare disorders for the development and testing of systematic large-scale diagnostic screening approaches on account of significant clinical and genetic heterogeneity, with pathogenic variants described in more than 340 genes (31). The study cohort consists of 98 WES diagnosed cases used to establish a reference dataset of gene expression (some of which have been published as single gene studies (4,32-53)) and 205 cases that remained inconclusive after WES (fig. S1). A single RNA-seq assay was performed per individual. A total of 101 samples were sequenced following a non-strand specific protocol and 202 following a strand-specific one using automated protocols minimizing sample handling and allowing highly reproducible results (Materials and Methods). We provide the gene expression count matrices, as well as the privacy-preserving 
medRxiv preprint doi: https://doi.org/10.1101/2021.04.01.21254633; this version posted May 16, 2021. The copyright holder for this preprint (which was not certified by peer review) is the author/funder, who has granted medRxiv a license to display the preprint in perpetuity.

It is made available under a CC-BY-NC-ND 4.0 International license .

count matrices of split and unsplit reads overlapping annotated splice sites, which can then be integrated by external users through DROP (Data availability).

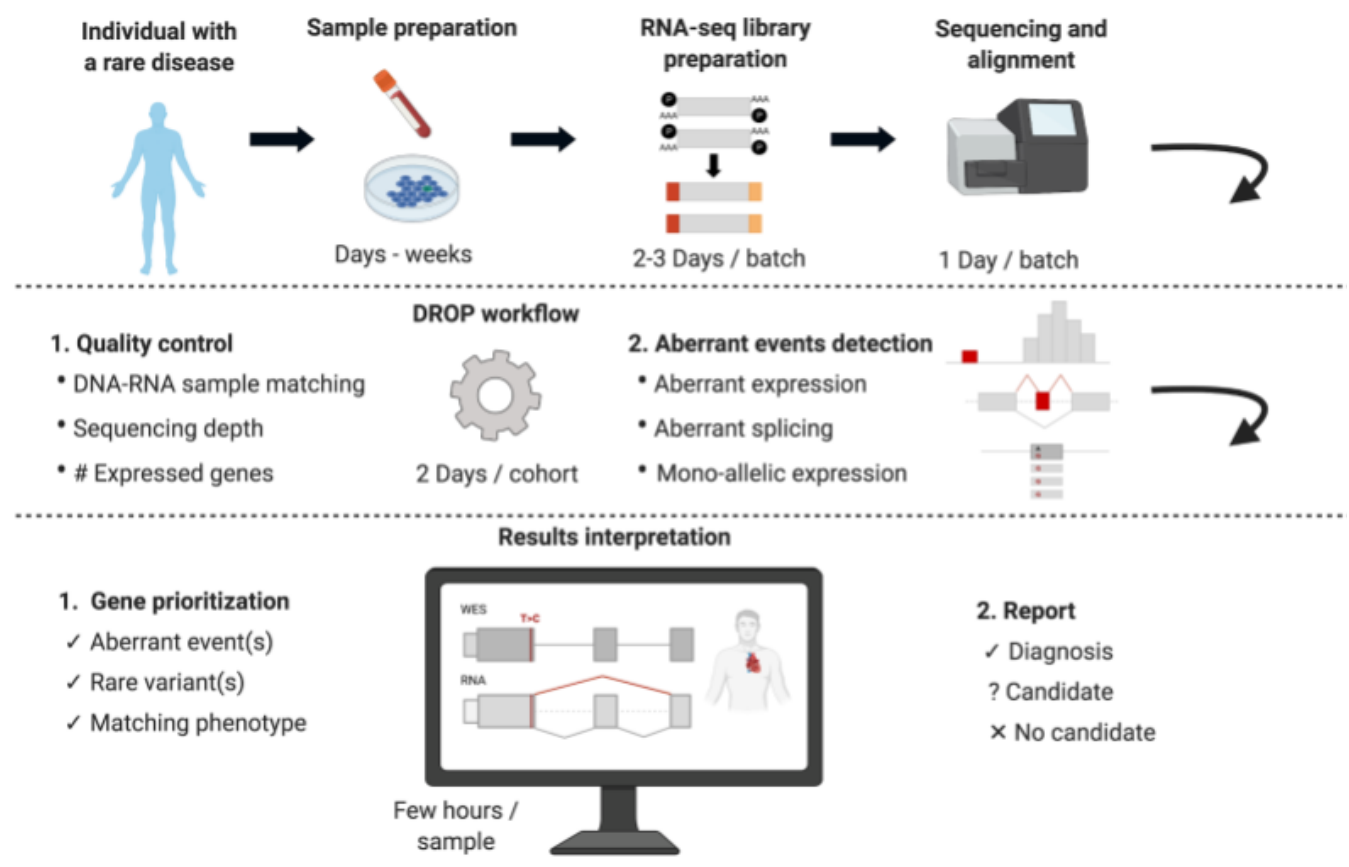

Fig. 1. Experimental design of an RNA-seq based diagnostic study. First, individuals suspected of a Mendelian disorder are recruited for DNA sequencing. In addition, patient biopsy material is collected during the routine medical examination and prepared for RNA extraction. The sample preparation process can take from hours for biopsies to weeks for establishing a cell culture. RNA sequencing is then performed followed by alignment and quality control. The generated data go through DROP which consists of quality control steps and detection of aberrant RNA expression events. The results are then interpreted by sample, including association of aberrant RNA expression events with rare variant(s) and the function of affected genes with the patient phenotype, which can lead to new diagnoses or candidates. Experience-based estimated durations are provided for each step.

After alignment, RNA-seq data were analyzed using the computational workflow DROP (30), which ensures reproducibility, robustness, and scalability (Fig. 1, Materials and Methods). Quality control metrics were computed including the sequencing depth and percentage of high-quality reads aligned (using RNA-SeQC (54)), and the number of expressed genes per sample using DROP (fig. S2). DROP also computes the percentage of matching DNA-RNA 
medRxiv preprint doi: https://doi.org/10.1101/2021.04.01.21254633; this version posted May 16, 2021. The copyright holder for this preprint (which was not certified by peer review) is the author/funder, who has granted medRxiv a license to display the preprint in perpetuity. It is made available under a CC-BY-NC-ND 4.0 International license .

variants to control for sample mismatches, which allowed us to reassign ten RNA-seq samples to their corresponding DNA (fig. S3, Materials and Methods). Afterward, DROP calls aberrant expression, aberrant splicing, and MAE using the statistical methods OUTRIDER (55), FRASER (56), and a negative binomial test (23), respectively. This yielded a median of 29 aberrant genes per sample, including eight where variants have been reported to cause a Mendelian disease in humans (OMIM (57), fig. S4). Aberrant events involving known disease-associated genes were then inspected manually in a case-by-case fashion comparing patient phenotype information with the phenotypes and mode of inheritance associated with the disease-associated gene (Fig. 2). For plausible candidate genes, we next inspected the sequencing data and searched for causative variants called by either WES or RNA-seq, and in some cases performed WGS followed by segregation analysis of the likely pathogenic variants (Fig. 2). This procedure led to a genetic diagnosis of 32 unsolved cases, representing 16\% (95\%CI: 11\%-22\%) of the WES-inconclusive cohort (Table 1, fig. S1), seven of which were previously published $(23,58)$, and ten described in a companion manuscript (59). Among the 46 causative variants in these 32 cases, 13 (28\%) were already classified as pathogenic or likely pathogenic, $10(22 \%)$ required functional validation, 11 (24\%) were not prioritized during WES-analysis, and $12(26 \%)$ were not captured by WES. Three $(25 \%)$ of the uncaptured group required WGS to identify the causative variant, while the other nine $(75 \%)$ were detected using variant calling from RNA-seq (Table 1$)$. In addition to the solved cases, we identified potential candidates in 12 cases: in 8 we identified a likely pathogenic change at the transcript level but have been unable to pinpoint the causative variant, and in 4 cases we identified aberrant expression and likely deleterious variants in candidate genes, representing likely novel disease genes (table S2, Fig. 2, fig. S1, fig. S4). These candidate cases 
medRxiv preprint doi: https://doi.org/10.1101/2021.04.01.21254633; this version posted May 16, 2021. The copyright holder for this preprint (which was not certified by peer review) is the author/funder, who has granted medRxiv a license to display the preprint in perpetuity.

It is made available under a CC-BY-NC-ND 4.0 International license .

are currently being investigated in follow-up studies. Here, we outline each screening step for the detection of aberrant events.

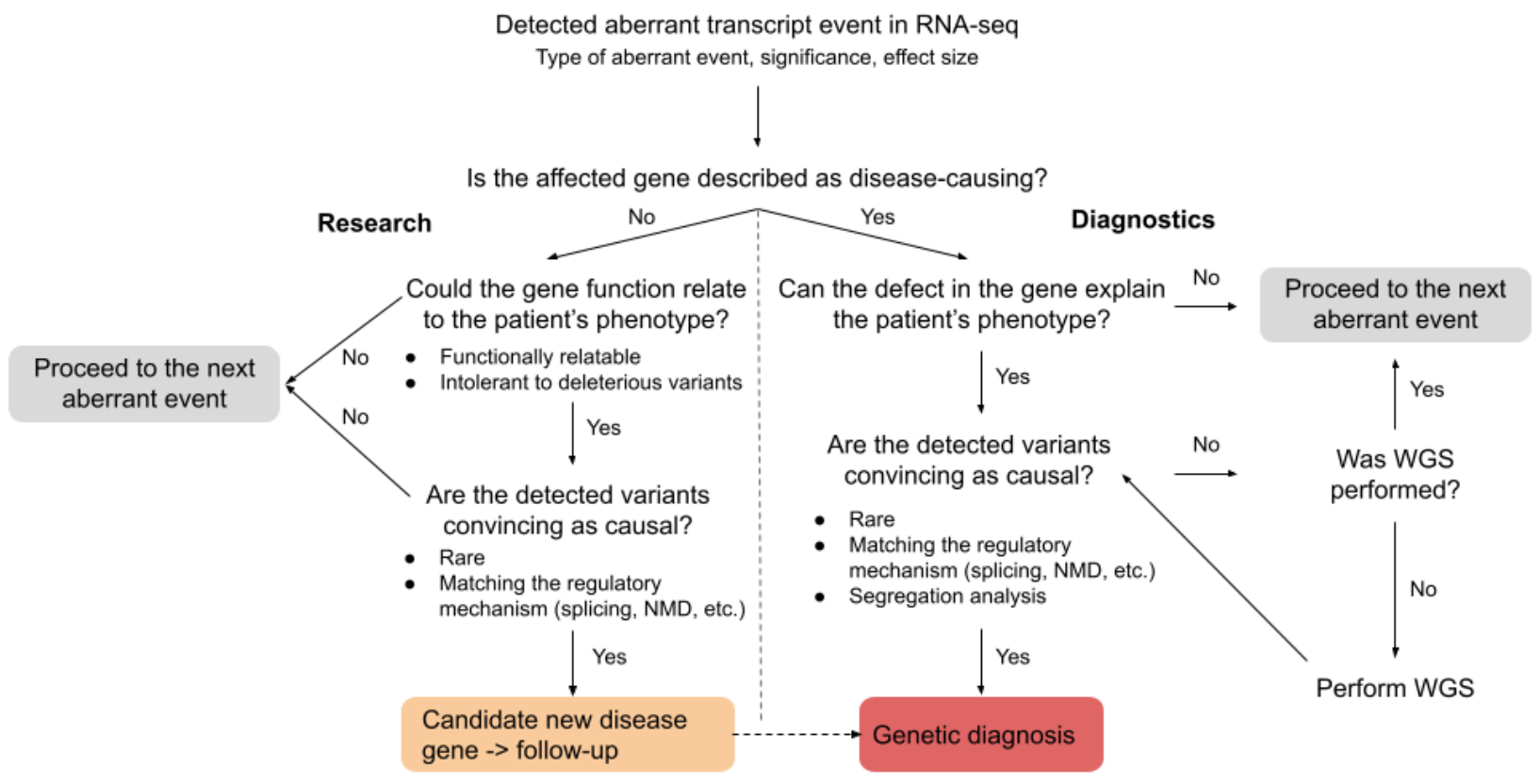

Fig. 2. RNA-seq based diagnostic flow chart. Flow diagram showing the diagnostic decision guideline after detecting a gene with an aberrant event in RNA-seq data. Identification of an aberrant event can lead to genetic diagnosis (diagnostic setting), lead to discovery of a candidate new disease gene (research setting), or alternatively be of unlikely diagnostic significance, after which the next aberrant event is analyzed following the same way path.

\section{Aberrant Expression}

A total of 14,100 genes were considered in the strand-specific subset and 14,399 in the non-strand-specific subset (fig. S3, coverage filter, Materials and Methods). In both cohorts, this represented $66 \%$ of the OMIM genes and $90 \%$ of the mitochondrial disease genes (Materials and Methods). OUTRIDER called a median of two underexpression outliers per sample, including one known disease gene, and a median of one overexpression outlier per sample, at a false discovery rate (FDR) less than 0.05 (Fig. 3A). 
medRxiv preprint doi: https://doi.org/10.1101/2021.04.01.21254633; this version posted May 16, 2021. The copyright holder for this preprint (which was not certified by peer review) is the author/funder, who has granted medRxiv a license to display the preprint in perpetuity.

It is made available under a CC-BY-NC-ND 4.0 International license .

We systematically assessed how expression outliers are associated with classes of rare variants and classes of genes (Materials and Methods). We found at least one rare (minor allele frequency $<0.001)$ variant in $36 \%$ (293 out of 812 ) of underexpression outlier genes. This is a significantly higher proportion than what was observed in the overexpression and non-outlier genes, indicating a causal relationship (Fig. 3B). Notably, in 28\% (225 out of 812) of the underexpression outliers, the rare variant could directly (stop, frameshift) or indirectly (splice region - within 1-3 bases of the exon or 3-8 bases of the intron) lead to a premature stop codon, triggering the nonsense-mediated decay (NMD, Fig. 3B). This is in agreement with previous reports describing the association between rare variants with aberrant expression in affected and non-affected individuals across various tissues (25,60-63). The remaining rare variants associated with the underexpression outliers were significantly enriched for coding, intronic, and variants in the untranslated regions (UTRs), indicating important regulatory roles of variants in these regions (Fig. 3B).
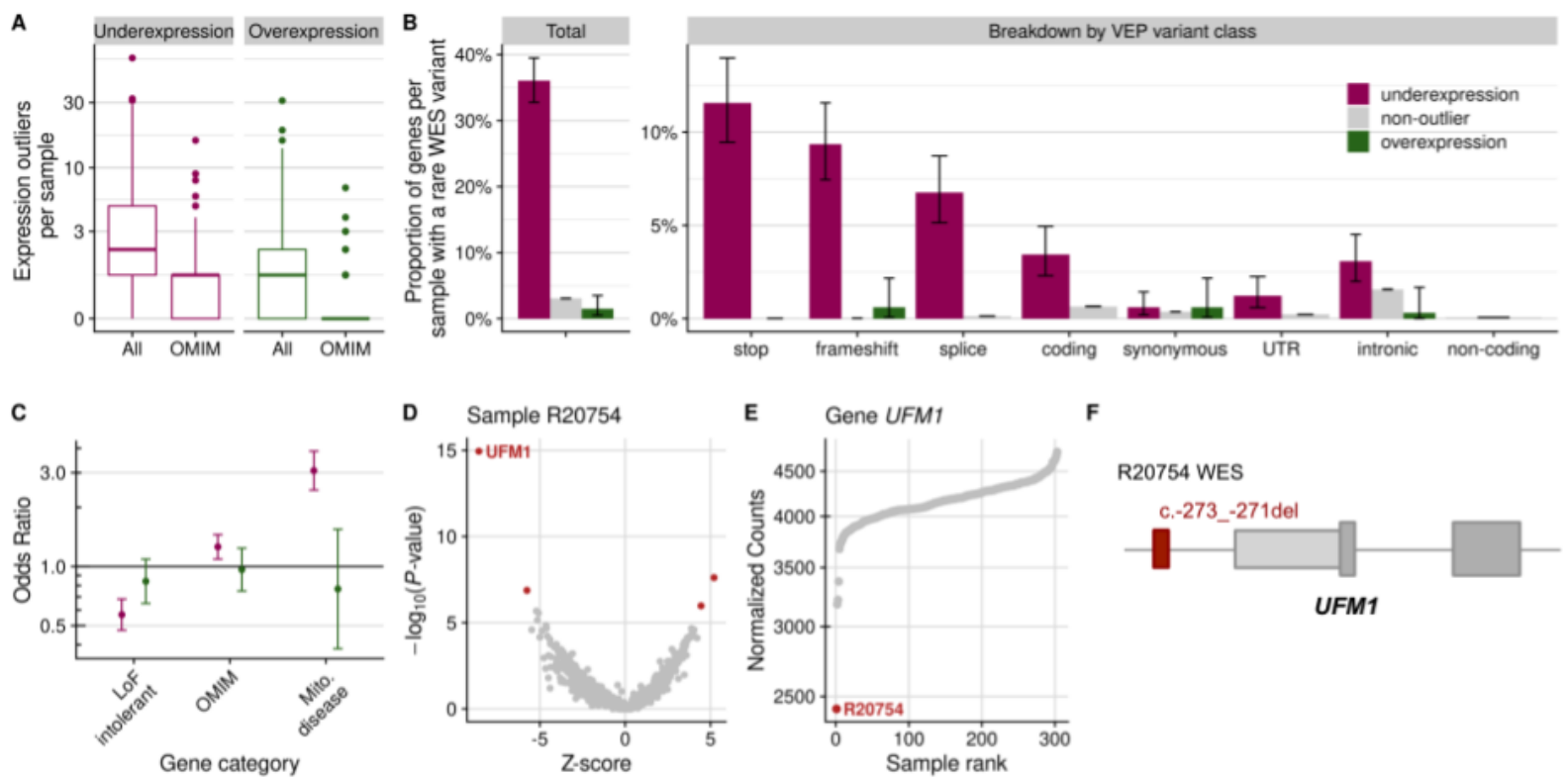
R20754 WES

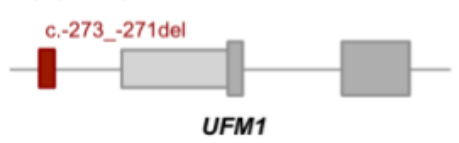


medRxiv preprint doi: https://doi.org/10.1101/2021.04.01.21254633; this version posted May 16, 2021. The copyright holder for this preprint (which was not certified by peer review) is the author/funder, who has granted medRxiv a license to display the preprint in perpetuity.

It is made available under a CC-BY-NC-ND 4.0 International license .

Fig. 3 Aberrant expression. (A) Distribution of genes per sample that were detected as expression outliers, for all genes and genes known to cause a disease (OMIM), stratified by outlier class. (B) Proportion of genes per sample with a WES rare variant among underexpression outliers, non-outliers, and overexpression outliers, for all rare variants and stratified by VEP variant classes (Methods). Error bars represent $95 \%$ confidence intervals of a binomial test. (C) Observed over expected number of overexpression and underexpression outliers (y-axis, log-scale) for loss-of-function intolerant genes, OMIM genes, and mitochondrial disease genes (x-axis). Error bars represent $95 \%$ confidence intervals of pairwise logistic regressions. (D) Gene-level significance $\left(-\log _{10}(P)\right.$, y-axis) versus Z-score, with UFM1 labeled among the expression outliers (red dots) of sample R20754. (E) Expression of UFM1 shown as normalized counts ranked across all samples, with the lowest expression in sample R20754. (F) Schematic depiction of the NM_016617.2:c.-273_-271del UFM1 deletion (red rectangle) detected by WES in sample R20754. Figure not shown at genomic scale. LoF: loss-of-function, VEP: variant effect predictor.

In agreement with observations in non-affected individuals (62), loss-of-function (LoF) intolerant genes were depleted for underexpression outliers (Fig. 3C), reflecting constrained expression. Given the clinical diagnosis of the individuals in our study, we observed an enrichment for OMIM genes (1.25-fold), and particularly mitochondrial disease genes (3-fold) among underexpression outliers (Fig. 3C). Overexpression outliers did not show an association with these gene categories, indicating them to be less clinically relevant. Collectively, these results support detection of underexpression outliers to guide towards a molecular diagnosis.

For candidate gene prioritization, we focused on underexpression rather than overexpression outliers because we presumed LoF to be a more likely pathomechanism of congenital metabolic disorders than dominant negative and gain-of-function (31). Aberrant expression was a major contributor to our diagnostic success with 25 out of $32(78 \%)$ newly diagnosed cases pinpointed as expression outliers (fig. S4 and S5). In figure 3 D-F we illustrate how expression outlier detection supported the identification of a causative variant in the case of a male with neonatal-onset leukodystrophy, nystagmus, and hearing impairment, whose initial WES analysis was inconclusive. RNA-seq analysis revealed two underexpression outliers, 
medRxiv preprint doi: https://doi.org/10.1101/2021.04.01.21254633; this version posted May 16, 2021. The copyright holder for this preprint (which was not certified by peer review) is the author/funder, who has granted medRxiv a license to display the preprint in perpetuity.

It is made available under a CC-BY-NC-ND 4.0 International license .

among which was the ubiquitin-fold modifier 1 gene, UFM1 (MIM: 610553, Fig. 3D). In this sample, we found the lowest expression of UFM1 among all 303 samples (Fig. 3E). Reinspection of WES revealed a 3-bp homozygous deletion located in the promoter region (NM_016617.2:c.-273_-271del, Fig. 3F), which was initially not prioritized during WES analysis due to its location. This variant has recently been reported to significantly reduce promoter and transcriptional activity and was considered to be pathogenic in cases of hypomyelinating leukodystrophy (64). This case exemplifies how the detection of aberrant expression enables the reprioritization of variants located in the non-coding regions.

Detection of aberrant expression can directly pinpoint the causative gene, but it can also reflect downstream effects, which provides functional evidence and can guide or support diagnostic interpretation. This is exemplified in a case diagnosed after WES identified a 3-bp homozygous deletion (NM_133259.3:c.2595_2597del, p.Val866del) in the LRPPRC gene (MIM: 607544, (41)), encoding for a leucine-rich PPR motif-containing protein that forms a ribonucleoprotein complex with SLIRP to regulate the stability of mature mitochondrial transcripts (65). OUTRIDER detected a significant downregulation of 11 mitochondrial DNA (mtDNA)-encoded genes in this case (fig. S6), thus supporting the functional defect of LRPPRC, and contributing to the enrichment of mitochondrial disease genes among underexpression outliers.

\section{Aberrant Splicing}

Aberrant splicing can be caused by variants in the canonical splice sites, but also by variants in weak splice sites or in less clearly mapped splicing regulatory sequences such as the 
medRxiv preprint doi: https://doi.org/10.1101/2021.04.01.21254633; this version posted May 16, 2021. The copyright holder for this preprint (which was not certified by peer review) is the author/funder, who has granted medRxiv a license to display the preprint in perpetuity.

It is made available under a CC-BY-NC-ND 4.0 International license .

exonic and intronic splicing enhancers and silencers (66). The aberrant splicing caller FRASER (56) is based on annotation-free intron-centric metrics (67). Specifically, FRASER uses percent-spliced-in of alternative donor sites $\left(\psi_{5}\right)$ and alternative acceptor sites $\left(\psi_{3}\right)$ to detect exon skipping, exon creation, exon truncation, and exon elongation, in addition to splicing efficiency $(\theta)$ to detect intron retention (Materials and Methods). After applying FRASER with the recommended cut-offs, we obtained a median of 23 genes with at least one aberrantly spliced junction per sample (FDR $<0.1$ and differential $\psi_{5}, \psi_{3}$, or $\theta$ greater than 0.3 ), including 7 disease genes (Fig. 4A).
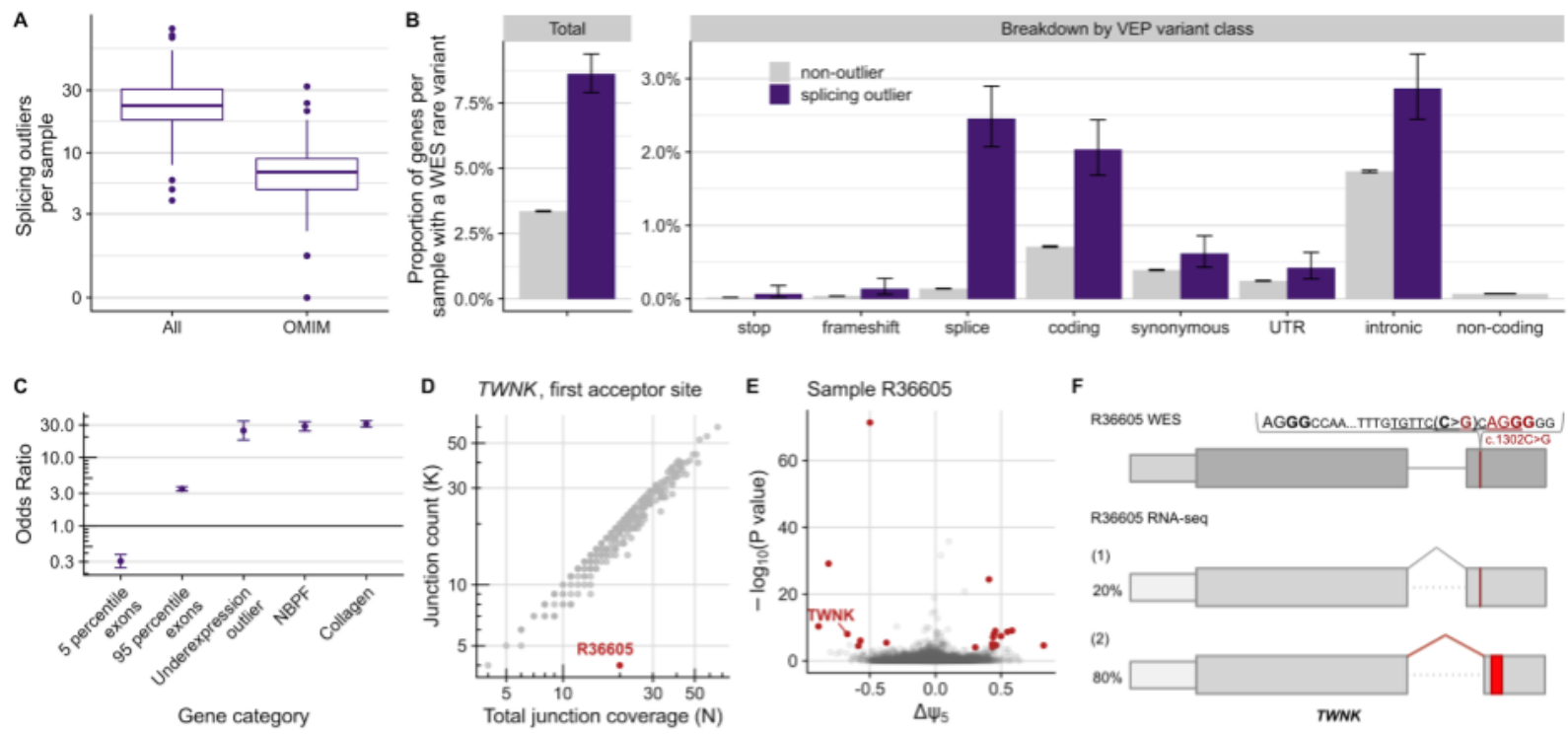

Fig. 4. Aberrant splicing. (A) Distribution of genes per sample that had at least one splicing outlier, for all genes and genes known to cause a disease (OMIM). (B) Proportion of genes per sample with a WES rare variant among the splicing outliers (purple) and the non-outliers (gray), for all rare variants and stratified by variant effect predictor classes. Error bars represent $95 \%$ confidence intervals of a binomial test. (C) Observed over expected number of splicing outliers on different gene categories. NBPF and collagen genes were chosen due to their high number of exons and due to collagen genes alternative splicing in a developmental-stage manner (68) and NBPF genes having a repetitive structure, which exposes them to illegitimate recombination (69). Error bars represent 95\% confidence intervals of pairwise logistic regressions. (D) Split-read counts (y-axis, gray junction on panel F) of the first annotated junction of $T W N K$ against the total split-read coverage (x-axis, gray and red junctions on panel F) of the first donor site of $T W N K$. Many samples are not exclusively using the annotated junction (scattered below the diagonal), leading to a reference $\psi_{5}$ for the annotated junction of $87 \%$. The observed $\psi_{5}$ for the first acceptor site of $T W N K$ in the outlier sample is $20 \%$ (obtained by 
medRxiv preprint doi: https://doi.org/10.1101/2021.04.01.21254633; this version posted May 16, 2021. The copyright holder for this preprint (which was not certified by peer review) is the author/funder, who has granted medRxiv a license to display the preprint in perpetuity.

It is made available under a CC-BY-NC-ND 4.0 International license .

dividing the junction reads by the total junction coverage, $4 / 20)$. (E) Gene-level significance $\left(-\log _{10}(P)\right.$, y-axis) versus differential splicing effect (observed minus expected usage proportion of the tested donor site, $\Delta \psi_{5}$, x-axis) for the alternative splice donor usage in sample R36605. Gene-level significance is obtained by multiple testing correction across all introns per gene (56). Outliers are marked in red and the gene TWNK explicitly labeled. The $\Delta \psi_{5}$ value for the first donor site of $T W N K$ in this sample is $-0.67=0.2-0.87$. (F) Schematic depiction of the synonymous NM_001163812.1:c.1302C $>$ G (p.Ser434=) TWNK variant and its consequence on the RNA level, activating a new acceptor site (ACGG in red). and leading to the creation of a premature termination codon (red rectangle) in sample R36605. The percentage of each transcript isoform is shown next to it. Figure not shown at genomic scale.

In our cohort, $8.5 \%$ (487 out of 5,649$)$ of aberrantly spliced genes contained rare variants, a proportion significantly higher than non-splicing outlier genes (Fig. 4B). As expected, many of these rare variants are located in the splice region $(60,61)$. Moreover, we observed an enrichment of coding and intronic variants (Fig. 4B), underscoring the role of coding and intronic sequences in splicing. Although we controlled for multiple testing within genes (56), genes with more exons ( $\mathrm{n}>95^{\text {th }}$ percentile) had enrichment of aberrant splicing, while genes with fewer exons (n $<5^{\text {th }}$ percentile) showed less aberrant splicing (Fig. 4C). In particular, the neuroblastoma breakpoint family (NBPF) of genes, which have 35 exons per gene, and collagen genes, which have 54 exons per gene, compared to a median of 17 exons in genes detected by FRASER, appeared to be more susceptible to aberrant splicing. In addition, splicing outliers were found to be 25-fold enriched among underexpression outliers (Fig. 4C), some of which could be explained due to the creation of an aberrantly spliced isoform containing a premature termination codon (PTC) ultimately resulting in transcript degradation by NMD.

Aberrant splicing was considered disease-causative in 18 out of 32 cases $(56 \%), 11$ of which were in combination with supportive aberrant expression data (fig. S4C). In Fig. 4D to F, we showcase how aberrant splicing detection helped identify the disease-causing gene defect in a 
medRxiv preprint doi: https://doi.org/10.1101/2021.04.01.21254633; this version posted May 16, 2021. The copyright holder for this preprint (which was not certified by peer review) is the author/funder, who has granted medRxiv a license to display the preprint in perpetuity. It is made available under a CC-BY-NC-ND 4.0 International license .

male patient with early-onset acute liver failure. In this sample, 38 aberrantly spliced genes were identified by FRASER, 13 of them on disease-causal genes. Among them was aberrant splicing and expression of TWNK (MIM: 606075). This gene encodes the twinkle mtDNA helicase that is critical for the efficient mtDNA replication and synthesis of the nascent D-loop strands (70). Autosomal recessive pathogenic variants in $T W N K$ are associated with disorders of mtDNA maintenance, including a hepatocerebral presentation associated with a mtDNA depletion (71). FRASER called a significant deviation from the canonical junction usage of the first intron (Fig. 4D), whereby an alternative acceptor within exon 2 was utilised, resulting in a frameshift and creation of a premature termination codon (Fig. 4F). Moreover, this aberrant splicing was associated with reduced level of the $T W N K$ transcript (fold change: 0.43 ) indicating NMD of some transcript isoforms. Reanalysis of WES data revealed a rare homozygous variant (NM_001163812.1:c.1302C $>\mathrm{G}$ ) in the second exon, which is predicted to have a synonymous effect (p.Ser434=). The variant is positioned four nucleotides upstream of an alternative splice junction (Fig. 4F), which corresponds to a weak splice site in controls $\left(\psi_{5}=9 \%\right)$. This variant is predicted (using the Human Splicing Finder in silico tool (72)) to disrupt the plausible exonic splicing enhancer sequences tgttcCca and ccCagg (Fig. 4F), thereby activating the weak splice site and eventually leading to a frameshift (p.416Glyfs*7). The activation of weak splice sites is a likely disease-causing phenomenon and is known to be recurrent, as we reported in an earlier study (23).

A particular value of RNA-seq lies in the quantification of different transcript isoforms. This is especially useful for transcripts with physiological presence of several alternative isoforms and in cases of aberrant splicing with a complex pattern, exemplified by a case with a 
medRxiv preprint doi: https://doi.org/10.1101/2021.04.01.21254633; this version posted May 16, 2021. The copyright holder for this preprint (which was not certified by peer review) is the author/funder, who has granted medRxiv a license to display the preprint in perpetuity.

It is made available under a CC-BY-NC-ND 4.0 International license .

homozygous splice region variant (NM_022915.3:c.179+3A>G) in the gene MRPL44 (MIM:

611849). This variant led to transcript depletion and three alternative isoforms with a PTC in each, in addition to the main transcript isoform that was present in less than $18 \%$ of all reads (fig. S7).

Mono-allelic expression

For heterozygous loci, the expression of only one of the two alleles is referred to as mono-allelic expression (MAE). Possible causes for MAE include one allele being transcriptionally silenced or post-transcriptionally degraded and can have genetic or epigenetic grounds $(73,74)$. As heterozygous variants alone are discarded when investigating autosomal recessive disorders, the detection of MAE of a rare variant indicates that both alleles are affected and enables their prioritization. We call MAE on heterozygous single nucleotide variants (SNVs) with at least 10 counts (median: 8,542 per sample, Fig. 5A) using the negative binomial test of Kremer et al. (23) (FDR $<0.05$ and allelic imbalance $>80 \%$, Material and Methods). We observed that MAE was more frequent towards the reference (median of 434) than towards the alternative allele (median 118, Fig. 5A). Subsetting to rare variants we found a median of 30 mono-allelic events towards the reference allele and 1 towards the alternative (Fig. 5A). 

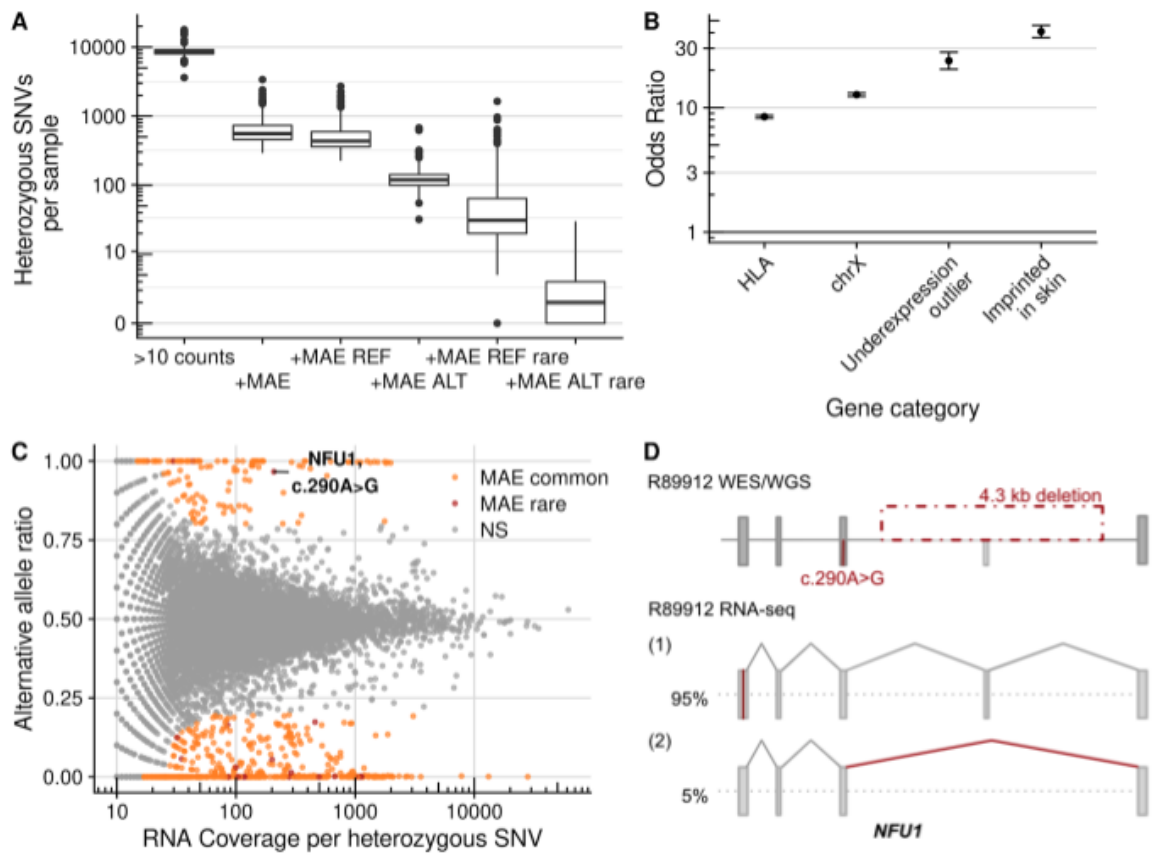

Fig. 5. Mono-allelic expression. (A) Distribution of heterozygous SNVs per sample for successive filtering steps from left to right: Heterozygous SNVs detected by WES with an RNA-seq coverage of at least 10 reads, where MAE is detected, where MAE of the reference is detected, where MAE of the alternative is detected, and subsetted for rare variants. (B) Odds ratio of MAE in genes with common variants only and with at least one rare variant across different gene categories. Error bars represent $95 \%$ confidence intervals of pairwise logistic regressions. (C) Alternative allele ratio (y-axis, alternative allele counts / total allelic counts) for the sample R89912 compared to the total allelic counts per SNV (x-axis) within the sample. Significant MAE in common variants are shown in orange and in rare variants in red, among which is the disease-causing SNV NM_001002755.2:c.290A>G NFU1. (D) Schematic depiction of the disease-causing $4.3 \mathrm{~kb}$ deletion and the c.290A $>$ G SNV in NFU1 and their consequence on the RNA level in sample R89912. The percentage of detected transcript isoform is shown next to it. Figure not shown at genomic scale. REF: reference, ALT: alternative, rare: minor allele frequency $<0.1 \%$, NS: not significant.

As expected from their biology, MAE was enriched among HLA, X-chromosomal, and imprinted genes (Fig. 5B). Moreover, we found a high enrichment of underexpression outliers (Fig. 5B), indicating that loss of expression of a single allele can be detected as an aberrant expression of the gene itself.

Detection of MAE helped to diagnose four cases, all coupled with aberrant expression (fig. S4). In one case, an infant male with severe Leigh syndrome and complex I deficiency, 
medRxiv preprint doi: https://doi.org/10.1101/2021.04.01.21254633; this version posted May 16, 2021. The copyright holder for this preprint (which was not certified by peer review) is the author/funder, who has granted medRxiv a license to display the preprint in perpetuity. It is made available under a CC-BY-NC-ND 4.0 International license .

MAE of NFU1 (MIM: 608100) was identified (Fig. 5C) in combination with aberrant expression (fold change: 0.63 , fig. S5). NFU1 encodes a scaffold protein that facilitates the insertion of iron-sulfur clusters into the subunits of the respiratory chain complexes and lipoic acid synthase (75,76). Individuals harboring pathogenic biallelic NFU1 variants present with early-onset failure to thrive, pulmonary hypertension, encephalopathy, and neurological regression $(77,78)$. The mono-allelically expressed missense variant NM_001002755.2:c.290A >G (p.Va191Ala) with a CADD score of 28.6 was absent from gnomAD. Following this observation we initiated WGS, which revealed a $4.3 \mathrm{kbp}$ heterozygous deletion affecting exon 6 of the second allele, explaining the detected MAE (Fig. 5D). Proteomic analysis also found a severe reduction of NFU1 (fold change: 0.13 ) finally confirming the diagnosis (59). This case presents the first association of pathogenic NFU1 variants with Leigh syndrome, thus expanding the clinical phenotype. Interestingly, pathogenic variants in another iron-sulfur cluster scaffold gene, BOLA3 (MIM: 613183), and in a gene involved in iron-sulfur cluster biosynthesis, FDXR (MIM: 103270), have previously been reported to cause Leigh syndrome $(79,80)$.

Haploinsufficiency has been reported as a pathomechanism for more than 660 genes $(81,82)$. It appears especially important for neurodevelopmental disorders, where de novo variants are often found in haploinsufficient genes or regulatory non-coding regions $(83,84)$. Hence, although the majority of mitochondrial diseases are inherited in an autosomal recessive mode (31), we also considered the possibility of haploinsufficiency, which can be detected by a combination of underexpression and MAE. Three samples in our cohort were solved with known haploinsufficient genes (MEPCE (MIM: 611478, ref. (45)), SON (MIM: 182465), and CHD1 (MIM: 602118), Table S3). They were all called outliers with close to $50 \%$ reduction in 
medRxiv preprint doi: https://doi.org/10.1101/2021.04.01.21254633; this version posted May 16, 2021. The copyright holder for this preprint (which was not certified by peer review) is the author/funder, who has granted medRxiv a license to display the preprint in perpetuity. It is made available under a CC-BY-NC-ND 4.0 International license .

expression level (fold change: 0.56, 0.61, and 0.64, respectively, fig. S5). Each of these genes had heterozygous protein-truncating variants suggesting that NMD acted on the transcript originating from the alternative allele. This hypothesis was confirmed by MAE of the reference alleles $(88 \%, 91 \%, 75 \%$, respectively). Moreover, segregation analysis in each case confirmed that the protein-truncating variants occurred de novo. Altogether, these results demonstrate that aberrant expression callers controlling for hidden confounders such as OUTRIDER (55) are sufficiently sensitive to detect aberrant expression when only one allele is affected and may discover the pathological variant in autosomal dominant disorders, particularly those presenting haploinsufficiency.

\section{Variant calling in RNA-seq data}

Currently, the application of WGS is still emerging within a diagnostic setting, largely limiting the sequence analysis to coding variants detected by WES. Advantageously, RNA-seq is able to contribute to variant discovery (26) by covering UTRs and even, with a lesser sequencing depth, intronic regions, which are not well covered by exome-capturing kits (85). We called variants in our RNA-Seq data following GATK's best practices (Materials and Methods). To identify filtering criteria with a useful balance between recall and precision, we performed a benchmark using 210 RNA-Seq samples derived from suprapubic skin of the GTEx project (86), considering their corresponding WGS-based variants as the ground truth. This benchmark suggested the exclusion of regions with three or more variants within a $35 \mathrm{bp}$ window, repeat masked regions (87), and variants with less than three reads supporting the alternative allele. Filtering these variants yielded a precision of $95 \%(97 \%)$ and a recall of $40 \%(54 \%)$ for 
medRxiv preprint doi: https://doi.org/10.1101/2021.04.01.21254633; this version posted May 16, 2021. The copyright holder for this preprint (which was not certified by peer review) is the author/funder, who has granted medRxiv a license to display the preprint in perpetuity.

It is made available under a CC-BY-NC-ND 4.0 International license .

heterozygous (homozygous) variants, in genomic positions with an RNA coverage of at least three reads (fig. S8A, Materials and Methods). While a precision of $95 \%$ would not be recommended for genome-wide variant prioritization, we found it to be reasonable for variant detection in candidate genes identified by aberrant expression and splicing analyses. When applied to our rare disease compendium, these filters yielded a median of 44,154 variants per RNA-seq sample, in comparison to a median of 63,666 variants found by WES (fig. S8B), including a median of 19,252 variants not called by WES. As expected, RNA-seq was particularly helpful in revealing variants in the untranslated regions $(40 \%$ RNA-seq only in 5'UTR and 75\% in 3'UTR, Fig. 6A). Coverage of intronic regions increased by one third by using RNA-seq based calling, which was specifically helpful for detecting deep intronic splice-altering variants (Fig. 6B).
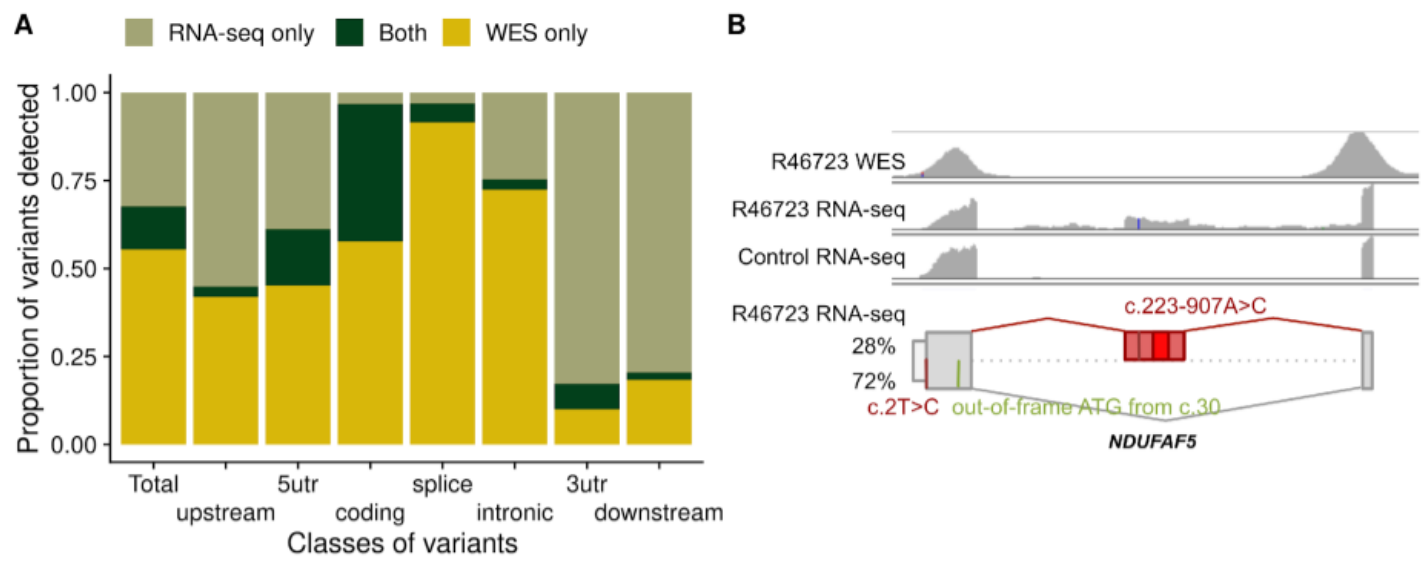

Fig. 6: RNA-seq variant calling. (A) Median across samples of the proportion of variants called only by WES, only by RNA-seq, and by both technologies, in total and stratified by variant classes. Of note, over $50 \%$ of variants in coding regions are called only by WES, probably because of RNA-seq limitations including that not all the genes are expressed in fibroblasts, the uneven read coverage along the transcript, and because the expression level of variant-carrying alleles must be high enough to yield sufficient RNA-seq read coverage. (B) Rows 1 - 3: WES and RNA-seq coverage of the affected sample (R46723) and a representative control using IGV. The created exon and a variant are seen in the affected RNA profile, but not covered in the corresponding WES and not present in the control. Bottom row: schematic depiction of the NM_024120.4 c.2T $>C$ and c.223-907A $>C$ variants and their consequence on the RNA level with an out-of-frame ATG (in green), and a cryptic 
medRxiv preprint doi: https://doi.org/10.1101/2021.04.01.21254633; this version posted May 16, 2021. The copyright holder for this preprint (which was not certified by peer review) is the author/funder, who has granted medRxiv a license to display the preprint in perpetuity.

It is made available under a CC-BY-NC-ND 4.0 International license .

exon with the PTC (bright red rectangle) on NDUFAF5. The percentage of detected transcript isoform is shown next to it. Figure not shown at genomic scale.

RNA-seq variant calling identified the causative variant in nine cases missed by WES, all deep intronic (Table 1 and Fig. 6B), and thereby negating the need to perform WGS. All of these cases were already candidates identified via aberrant expression and/or splicing analyses. One was a female suspected mitochondrial disease patient, presenting early in infancy with failure to thrive, complex I deficiency, and elevated lactate. FRASER detected aberrant splicing in the NDUFAF5 gene (MIM: 612360), encoding a complex I assembly factor, highlighting a cryptic exon in intron 1, present in $28 \%$ of the transcript (Fig. 6B). This 258 -nt cryptic exon is in frame and predicted to lead to an extension of the open reading frame by 31 amino acids before encountering a PTC (Fig. 6B). RNA-seq variant calling revealed a rare intronic variant (NM_024120.4:c.223-907A>C) within the cryptic exon (Fig. 6B). This variant has recently been described in a single patient, with cDNA studies supporting the creation of a new exonic splicing enhancer and the same aberrant splicing (88). Moreover, WES had identified an unreported start-loss heterozygous variant (NM_024120.4:c.2T >C). This variant disrupts the start codon, with the next available ATG out-of-frame at position c.30. Pathogenic variants in NDUFAF5 have been associated with an early-onset complex I deficiency, characterized by developmental delay, failure to thrive, hypotonia, and seizures (88), in agreement with the clinical presentation of the investigated individual. This intronic variant was also found associated with the inclusion of the same cryptic exon in another unrelated RNA-seq diagnosed case from our compendium, where it is in trans with a heterozygous frameshift NM_024120.4:c.605dup which causes aberrant expression (Table 1). Notably, variant calling in RNA-seq data fails in intergenic and 
medRxiv preprint doi: https://doi.org/10.1101/2021.04.01.21254633; this version posted May 16, 2021. The copyright holder for this preprint (which was not certified by peer review) is the author/funder, who has granted medRxiv a license to display the preprint in perpetuity. It is made available under a CC-BY-NC-ND 4.0 International license .

intronic regions, as well as in genes that are not expressed. Thus, the increased power of WGS in calling all genetic variation is still unquestionable, though the interpretation of cumbersome WGS datasets could be streamlined through the incorporation of RNA-seq data (Fig. 2).

Overview of the diagnosed cases

In a diagnostic setting, the value of RNA-seq lies in the functional assessment of often unpredictable effects of variants, leading to their validation and (re)prioritization, or shedding light on the non-coding regions and more complex pathomechanisms. As seen from the 32 cases diagnosed using RNA-seq, this application enabled the detection of a broad spectrum of molecular pathomechanisms driven by rare variants, including aberrant expression caused by variants in the promoter, deep intronic variants generating cryptic exons, and the combined deleterious effect of two common variants in cis (Table 1, Fig. 7).

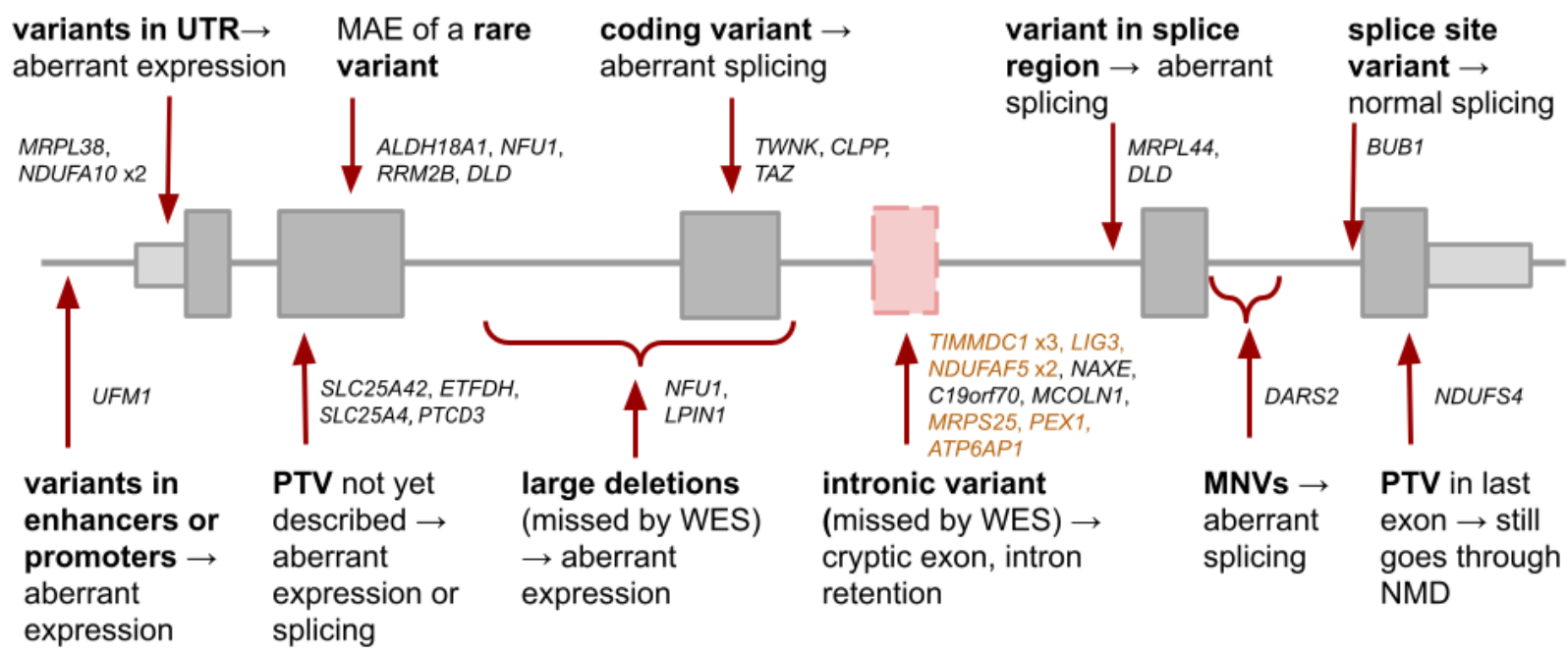

Fig 7. RNA-seq captures a broad spectrum of mechanisms of action of pathogenic variants. Summary of variants and their effect on transcript across 33 cases from our cohort, where the capture of a transcript event by RNA-seq enabled establishing genetic diagnosis in 32 and rejecting a candidate gene in one case, highlighting the value of transcriptomics as a tool in diagnostics. Each gene represents one case, except for NFU1 that belongs to two categories. Highlighted in orange are the nine cases where the intronic variant was missed by WES, but called by 
medRxiv preprint doi: https://doi.org/10.1101/2021.04.01.21254633; this version posted May 16, 2021. The copyright holder for this preprint (which was not certified by peer review) is the author/funder, who has granted medRxiv a license to display the preprint in perpetuity.

It is made available under a CC-BY-NC-ND 4.0 International license .

RNA-seq. Both large deletions were missed by WES and RNA-seq, therefore requiring WGS to be identified. PTV: protein-truncating variant. MNV: multi-nucleotide variant.

Returning to our reference set, of the 98 WES-diagnosed cases, 31 contained at least one rare protein-truncating variant (PTV) (fig. S1, table S3). Our RNA-seq-based workflow was able to re identify the causal gene in $84 \%$ (26 out of 31 ) of them (fig. S1, table S3). In the five remaining cases, RNA-seq failed to detect the aberrant transcripts for various reasons. In two cases, the causal genes (CCDC40, MIM: 613799; and F11, MIM: 264900) were not expressed in skin fibroblasts. In another two cases, both involving the TXNIP gene (MIM: 606599), the fold change was low (0.1 and 0.22), but a high dispersion of the gene's expression led to the cases not being called as outliers. In the last case, the patient harbored a heterozygous pathogenic missense variant in trans with a heterozygous PTV located in the first exon of the GFER gene (MIM: 600924) that leads to a frameshift and PTC after 16 amino acids. The clinical presentation of the patient and his sibling (not included in our cohort) include exercise intolerance, elevated lactate, and cataracts, which matched those described in other cases harbouring biallelic GFER variants (89), arguing in favor of pathogenicity. This case exemplifies that the functional impact of PTC is not always explained by NMD (90).

We inspected all rare homozygous variants and found that most of the rare stop and frameshift variants that occur outside the last exon and expressed in fibroblasts (Materials and Methods) indeed caused an expression outlier (fig. S9A). Only one rare homozygous frameshift in the last exon led to aberrant expression, which corresponded to the NDUFS4 case (Fig. 7, fig. S5), thus providing functional validation to solve the case. Similarly, most homozygous splice-site variants caused aberrant splicing (fig. S9B), with the exception of one case where 
medRxiv preprint doi: https://doi.org/10.1101/2021.04.01.21254633; this version posted May 16, 2021. The copyright holder for this preprint (which was not certified by peer review) is the author/funder, who has granted medRxiv a license to display the preprint in perpetuity. It is made available under a CC-BY-NC-ND 4.0 International license .

normal splicing was observed (variant NM_004336.4:c.1876+2A $>$ G in BUB1, Fig. 7, fig. S9C). In this respect, RNA-seq can also help to prevent a false assignment of pathogenicity. Finally, we tested the impact of all rare stop heterozygous SNVs that are not located in the last exon and found that more than $70 \%$ led to MAE of the reference allele (fig. S9D), which was a significantly higher proportion than the rest of variant classes and is in agreement with the results obtained from GTEx (61,91). This highlights the need for functional validation, such as RNA-seq, for PTV without reported pathogenicity (Fig. 6).

Reanalysis of the cohort published in 2017 (23) provided a genetic diagnosis to an additional five cases (two NDUFAF5, LPIN1, TAZ, NDUFA10; Table 1). The splicing defect in NDUFAF5 was not detected by the previously used LeafCutter method (92) but was found with FRASER. LeafCutter did find aberrant splicing in the LPIN1 and TAZ genes, but no variants were found to be conclusive. For the LPIN1 case, the causative variant (a 1,759 bp deletion) was detected in a follow-up study via WGS (Fig. 7). For the TAZ case, the causative variant was initially not prioritized because of its predicted consequence (56). In the NDUFA10 case, the previously used DESeq2 (93) for aberrant expression did find it to be an expression outlier, but the homozygous causal variants in the 5'UTR were not initially prioritized until later when the same aberrant expression was identified in the affected sibling (fig. S5). This shows the importance of data reanalysis by considering updates of the disease course and family segregation, applying state-of-the-art methods, and follow-up studies. 
medRxiv preprint doi: https://doi.org/10.1101/2021.04.01.21254633; this version posted May 16, 2021. The copyright holder for this preprint (which was not certified by peer review) is the author/funder, who has granted medRxiv a license to display the preprint in perpetuity.

Tissue-specific gene expression

An important limitation of the application of RNA-seq in a clinical setting is that the causal gene may not be expressed in the sampled tissue. To assess the impact of source material on transcriptome, we compared the expression of disease-associated genes for major disease categories (Fig. 8, Materials and Methods) across 49 tissues from healthy donors from the GTEx Consortium (86). The majority of genes of each disease category are expressed in any given tissue (except for ophthalmology and skeletal dysplasia genes in whole blood, Fig. 8A). Exceptionally, mitochondrial disease genes are ubiquitously expressed in all tissues, but other disease genes have a more pronounced tissue-specific expression profile, such as neurological genes in the brain (Fig. 8A). As in clinical practice biopsy of the least invasive tissue is desirable, we next focused on the clinically accessible tissues (CATs) - whole blood, Epstein-Barr virus (EBV)-transformed lymphocytes, skeletal muscle, and skin-derived fibroblasts (94). Fibroblasts were the CAT expressing the highest number of Mendelian disease genes $(2,564 ; 67 \%$; Fig. 8B). Although obtaining a skin biopsy is more invasive, skin-derived fibroblasts appear as a more useful resource than blood, showing a higher number of expressed genes in each disease category (which is significant for OMIM, neurology, ophthalmology, and skeletal dysplasia, Fisher's test $P<0.05)$. Fewer genes are also expressed in muscle for all disorders, except for neurology and neuromuscular disorders, confirming its utility (Fig. 8B). 
medRxiv preprint doi: https://doi.org/10.1101/2021.04.01.21254633; this version posted May 16, 2021. The copyright holder for this preprint (which was not certified by peer review) is the author/funder, who has granted medRxiv a license to display the preprint in perpetuity.

It is made available under a CC-BY-NC-ND 4.0 International license.

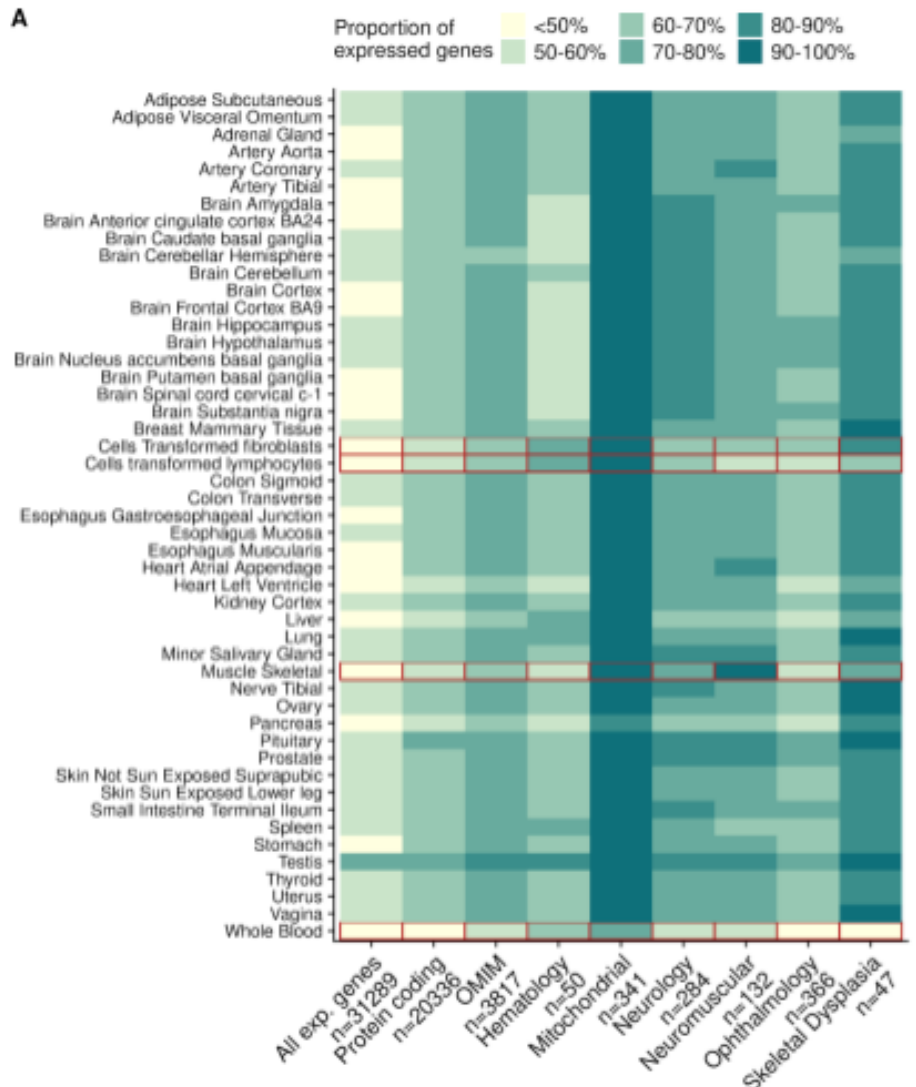

B

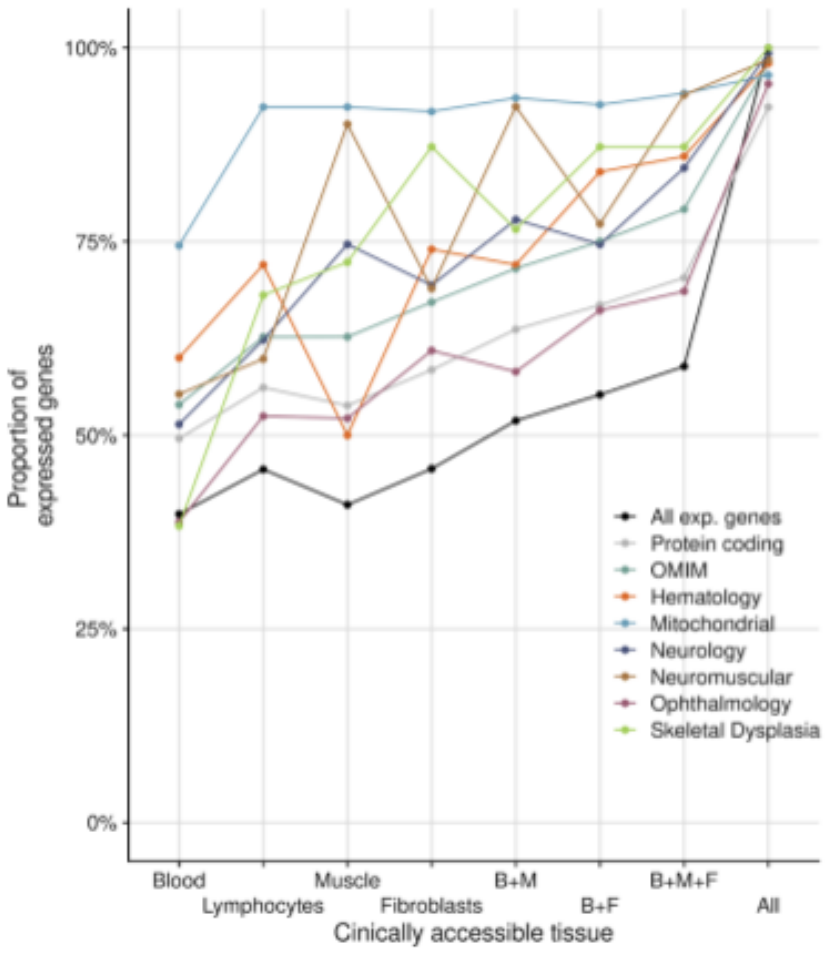

Fig 8. Tissue-specific gene expression. (A) Proportion of expressed genes from different categories across 49 GTEx tissues with the CATs delineated in red. (B) Proportion of expressed genes from different categories across CATs from GTEx, alone or in combination with another CAT. 'All' refers to all the 49 tissues, not just the CATs. B: blood, M: muscle: F: fibroblasts, CAT: clinically accessible tissue.

\section{Discussion}

We report the outcome of RNA-seq implementation as part of routine diagnostics for Mendelian diseases alongside WES in our centre for more than 300 individuals. We demonstrate application of the automated computational workflow DROP, showcase detailed diagnostics successes including instances of dominant mode of inheritance, and provide a diagnostic decision workflow integrating WES, WGS, and RNA-seq. The computational analysis time for RNA-seq is comparable to the genome pipelines, typically requiring less than a week from sample preparation to reported results. RNA-seq is based on the same technology as WES/WGS, 
medRxiv preprint doi: https://doi.org/10.1101/2021.04.01.21254633; this version posted May 16, 2021. The copyright holder for this preprint (which was not certified by peer review) is the author/funder, who has granted medRxiv a license to display the preprint in perpetuity. It is made available under a CC-BY-NC-ND 4.0 International license .

which is another favorable feature to consider when deciding to expand the diagnostic spectrum beyond the DNA sequence. Stringent p-value driven results yield a manageable number of OMIM genes with aberrant RNA events (median $=8$ ), similar to the average number of biallelic rare non-synonymous variants inspected during diagnostic WES analysis of autosomal recessive disorders. In this study, cumulative evidence from WES and RNA-seq supported the genetic diagnosis in $16 \%$ of WES-inconclusive cases. This number falls within the range of other RNA-seq studies with unrestricted inclusion criteria ranging from 7.5-18\% (fig. S10), and a hypothetical yield of $13.5 \%$ after retrospectively analyzing a cohort of WES-diagnosed patients (95), thereby reflecting the likely expected additional value of RNA-seq as a complement to WES.

The clinical significance of any given genetic variant falls along a gradient, ranging from those in which the variant is almost certainly pathogenic for a disorder, to those that are almost certainly benign (21). The clinical interpretation of variants is based on cumulative evidence from population-wide frequency, computational prediction, functional data, and segregation patterns. Findings from RNA-seq contribute evidence and may validate predicted pathogenic or likely pathogenic variants, reclassify VUS or benign variants, and lead to the detection of variants undetected by WES or overlooked by WES data inspection. Specifically, the value of RNA-seq is to provide functional evidence on variants affecting gene expression and splicing. Loss-of-function variation in disease genes represents the strongest evidence for pathogenicity. RNA-seq allows the detection of non-coding loss-of-function variation (96), including splice defects leading to the non-functional mRNA isoforms and variants abolishing transcription, 
medRxiv preprint doi: https://doi.org/10.1101/2021.04.01.21254633; this version posted May 16, 2021. The copyright holder for this preprint (which was not certified by peer review) is the author/funder, who has granted medRxiv a license to display the preprint in perpetuity.

It is made available under a CC-BY-NC-ND 4.0 International license .

which remain a challenge to predict from DNA sequence alone. Moreover, RNA-seq allows the validation or invalidation of (computational) predictions including splice site dinucleotide and NMD by providing quantitative measures of the actual fraction of affected transcripts. In this respect, RNA-seq could become the first step in the systematic inclusion of functional data together with genetic and phenotypic information which can relatively easily be implemented in the diagnostic workflow.

RNA-seq relies on taking additional patient biopsies in addition to a sample for DNA extraction and requires early consideration in the diagnostic process. Specifically, for severe life-threatening diseases with fast progression, we recommend establishing skin biopsies in the routine process in parallel to genome-based diagnostics. As we demonstrate, fibroblast cell lines express the majority of OMIM disease genes. Moreover, fibroblast cell lines can be differentiated into other cell types to more closely reflect the disease-affected tissue (26) or into pluripotent stem cells, where as many as 27,046 genes are expressed (63,97). Importantly, patient-derived cell lines not only allow functional studies of the disease of the patient but also provide a DNA resource for emerging sequencing technologies such as long read sequencing (98). One limitation of cell lines, in contrast to direct biopsies such as whole blood samples, is the time and effort needed for their growth. Therefore, in urgent situations (e.g., neonatal cases), blood sampling is preferred as it can be processed immediately.

There have been concerns regarding the use of fibroblasts to study pathological effects in diseases not affecting the skin. One concern is that the gene or its relevant isoform may be not expressed in fibroblast cell lines. Resources such as GTEx, Panel Analysis of Gene Expression 
medRxiv preprint doi: https://doi.org/10.1101/2021.04.01.21254633; this version posted May 16, 2021. The copyright holder for this preprint (which was not certified by peer review) is the author/funder, who has granted medRxiv a license to display the preprint in perpetuity.

It is made available under a CC-BY-NC-ND 4.0 International license .

(PAGE, (26)), or MAJIQ-CAT (94) allow expression of candidate genes and isoforms to be checked in clinically accessible tissues and cell types. Here, using GTEx, we demonstrate skin-derived fibroblasts to capture the majority of disease genes for major disease categories. Moreover, so long as the potential causal genes are expressed, non-affected tissues have the advantage that the transcriptome-wide consequences of the diseases are limited and hence the causal defects can more clearly stand out. Another concern is that pathogenic variants affect tissue-specific regulatory elements such as transcription factor binding sites or binding sites of tissue-specific splicing factors. However, strong regulatory effects, which one could expect for monogenic disorders, may rather be constitutive. This is the case for NMD (91). Also, a minor proportion of variants found in GTEx associated with splicing show tissue-specific effects (99). Overall, more studies are needed to assess the proportion of pathogenic variants altering tissue-specific regulatory elements.

With increasing adoption of RNA-seq in Mendelian disease diagnostics, we foresee the need for extended clinical guidelines, akin to the update of the ACMG/AMP guidelines necessitated by the uptake of WES as a standard diagnostic approach (21). These extended guidelines will need a concerted discussion across the community, regarding effect sizes and statistical cutoffs to define a pathological expression phenotype. Moreover, community-accepted criteria will be needed to assign the likelihood of pathogenicity for genomic variants, integrating RNA-seq based evidence with current features including annotations of genetic variants, computational predictions, frequency, and segregation patterns. 


\section{Materials and Methods}

\section{Compendium}

A total of 303 individuals with a suspected mitochondrial disorder were recruited (Table S1). WES and RNA-seq were performed in all of them. The compendium includes 70 individuals from the Kremer et al. study (23), 152 individuals from a multi-omics study (59), and 81 additional individuals recruited for this study. Three cases further required WGS as they were candidates from RNA-seq, but no conclusive variants were found via WES or RNA-seq.

\section{Cell culture}

Primary fibroblast cell lines obtained from patient skin biopsy were cultured in high glucose

DMEM (Life Technologies) supplemented with 10\% FBS, 1\% penicillin/streptomycin, and $200 \mu \mathrm{M}$ uridine at $37^{\circ} \mathrm{C}$ and $5 \% \mathrm{CO}_{2}$. All fibroblast cell lines tested negative for mycoplasma contamination. 
medRxiv preprint doi: https://doi.org/10.1101/2021.04.01.21254633; this version posted May 16, 2021. The copyright holder for this preprint (which was not certified by peer review) is the author/funder, who has granted medRxiv a license to display the preprint in perpetuity.

Whole exome sequencing

DNA was isolated from peripheral blood leukocytes or skin-derived fibroblasts using DNeasy Blood \& Tissue Kit (Qiagen, Hilden, Germany) according to the manufacturer's protocol. DNA concentration was measured using the Qubit ${ }^{\mathrm{TM}}$ dsDNA BR Assay Kit. $3 \mu \mathrm{g}$ of DNA was used for library preparation. Exonic regions from human DNA samples were enriched with the SureSelect Human All Exon V5/V6 kits from Agilent (Agilent Technologies, Santa Clara, CA, USA) and sequenced as 100 bp paired-end runs on Illumina HiSeq2500 or HiSeq4000 platforms (Illumina, San Diego, CA, USA). Reads were aligned to the human reference genome (UCSC build hg19) using Burrows-Wheeler Aligner v0.7.5a (100). Single nucleotide variants, as well as small insertions and deletions (<200 bp), were detected with SAMtools v0.1.19 (101) and GATK v3.8 (102).

Whole genome sequencing

One WGS library was established using a MGIEasy DNA Library Prep Kit v1.1, according to the manufacturer's protocol and generated DNA nanoballs. Sequencing was performed using 100-bp paired-end reads on a MGISEQ-2000 using MGISEQ-2000RS High-throughput Sequencing Set PE100 v3.0. The other two WGS libraries were prepared with the TruSeq DNA PCR-Free Kit (Illumina). DNA was fragmented to an average length of 350 bp by sonication. Libraries were validated according to standard procedures and sequenced via $150 \mathrm{bp}$ paired-end on a NovaSeq 6000 platform. After removing adapter sequences and low-quality reads by Trimmomatic v0.39 (103), reads were aligned and variants were called using the same procedures described in the previous subsection. 
medRxiv preprint doi: https://doi.org/10.1101/2021.04.01.21254633; this version posted May 16, 2021. The copyright holder for this preprint (which was not certified by peer review) is the author/funder, who has granted medRxiv a license to display the preprint in perpetuity.

\section{Variant annotation and handling}

Variants were annotated for consequence, location, minor allele frequencies (from the 1000 Genomes Project (104) and gnomAD (105) cohorts), and deleteriousness scores using the R interface to the Ensembl Variant Effect Predictor (VEP) v1.32.0 (16,106). For variants that fell on multiple transcripts and had therefore multiple predicted consequences, the one with the highest predicted impact was selected (107). We considered a variant to be rare if the maximum minor allele frequency across both cohorts was lower than 0.001 and the frequency of the variant in our cohort was lower than 0.01. Variants are reported using the Human Genome Variation Society (HGVS) recommendations (108).

In order to detect whether a genomic position is expressed, we computed the RNA coverage using the coverage function from the GenomicAlignments R package v1.26.0 (109). We defined a position to be expressed if the mean coverage across all samples was greater or equal than 10 reads.

\section{RNA-sequencing}

RNA was isolated from the patient-derived skin fibroblasts with the RNeasy mini kit (Qiagen, Hilden, Germany) according to the manufacturer's protocol. RNA integrity number (RIN) was determined using the Agilent 2100 BioAnalyzer (RNA 6000 Nano Kit, Agilent Technologies, Santa Clara, CA, USA). Non-strand-specific RNA-seq was performed in 101 samples as previously described (23). The rest of the RNA samples were sequenced strand-specifically, where library preparation was performed according to the TruSeq Stranded mRNA Sample Prep LS Protocol (Illumina, San Diego, CA, USA). Specifically, $1 \mu \mathrm{g}$ of RNA was purified using 
medRxiv preprint doi: https://doi.org/10.1101/2021.04.01.21254633; this version posted May 16, 2021. The copyright holder for this preprint (which was not certified by peer review) is the author/funder, who has granted medRxiv a license to display the preprint in perpetuity. It is made available under a CC-BY-NC-ND 4.0 International license .

poly-T oligo-attached magnetic beads and fragmented. The RNA fragments were reverse transcribed with the First Strand Synthesis Act D mix. The second strand cDNA was generated with Second Strand Marking Mix that ensures strand specificity by replacing dTTP with dUTP. The resulting double-stranded cDNA was subjected to end repair, A-tailing, adaptor ligation, and library enrichment. The quality and quantity of the RNA libraries were assessed with the Agilent 2100 BioAnalyzer and the Quant-iT PicoGreen dsDNA Assay Kit (Life Technologies, Carlsbad, CA, USA). RNA libraries were sequenced as $100 \mathrm{bp}$ paired-end runs on Illumina HiSeq2500 or HiSeq4000 platforms. Reads from RNA-seq were demultiplexed and then mapped with STAR (v2.7.0a) to the hg19 genome assembly, with default parameters plus setting the twopassMode to 'Basic' to detect novel splice junctions (110).

\section{Variant calling in RNA-seq data}

Variants were called on RNA-seq data using GATK best practices for RNAseq short variant discovery (Online resources). Variants with a ratio of quality to depth of coverage $<2$, that were strand biased (Phred-scaled fisher exact score $>30$ ), or belonging to a SNP cluster (3 or more SNPs within a 35 bp window) were filtered out, as suggested by GATK. Furthermore, variants not contained in a repeat masked region (as defined by RepeatMasker v4.1.0 (87)), and with 3 or more reads supporting the alternative allele were prioritized. For the benchmark analysis, 210 RNA-Seq samples derived from suprapubic skin of the GTEx project (86) were used. Only genomic positions with an RNA coverage of at least 3 reads were considered. 
medRxiv preprint doi: https://doi.org/10.1101/2021.04.01.21254633; this version posted May 16, 2021. The copyright holder for this preprint (which was not certified by peer review) is the author/funder, who has granted medRxiv a license to display the preprint in perpetuity.

\section{Quality control}

Quality control was performed using RNA-SeQC v2.4.2 (54) and visualized using MultiQC v1.9 (111) to detect the percentage of reads falling in exonic regions, and with low quality. DROP (v1.0.3) was used to compute the total sequencing depth per sample, percentage of mapped reads, and number of expressed genes (30). DROP was also used to determine whether an RNA-seq sample matches its annotated DNA sample. A cutoff of 0.7 distinctly separated the matching with the non-matching DNA-RNA pairs.

\section{Detection of aberrant expression}

Detection of aberrant expression was fully based on DROP, v1.0.3 (30). We used as reference genome the GRCh37 primary assembly, release 29, of the GENCODE project (112) which contains 60,829 genes. We use the summarizeOverlaps function from the GenomicAlignments (109) $\mathrm{R}$ package to count reads that are paired with mates from the opposite strands (singleEnd $=$ FALSE). We only considered reads that fell completely within an exon or span two exons from the same gene via splicing (mode $=$ intersectionStrict). Reads that overlapped more than one feature were assigned to each of those features instead of being removed (inter.feature $=$ FALSE). Genes with a 95th percentile FPKM $<1$ were considered to be not sufficiently expressed and filtered out.

Expression outliers were found using OUTRIDER (54), a method that uses a denoising autoencoder to control for latent effects and returns multiple-testing corrected p-values (FDR) for each gene and sample. Significant events were defined as those with a FDR $\leq 0.05$. All aberrant events were further inspected using the Integrative Genome Viewer (113). 
medRxiv preprint doi: https://doi.org/10.1101/2021.04.01.21254633; this version posted May 16, 2021. The copyright holder for this preprint (which was not certified by peer review) is the author/funder, who has granted medRxiv a license to display the preprint in perpetuity.

\section{Detection of aberrant splicing}

Splicing outliers were obtained using the DROP (v1.0.3) module based on FRASER (56), an annotation-free aberrant splicing detection algorithm. FRASER uses a denoising autoencoder to control for latent effects and estimates splice-site level and gene-level multiple-testing corrected p-values for percent-spliced-ins and splicing efficiencies. Exon-exon and exon-intron junctions with $<20$ reads in all samples and for which the total number of reads at the donor and acceptor splice site is 0 in more than $95 \%$ of the samples were filtered out. From the FRASER output, splicing outlier genes were defined as those with a FDR $\leq 0.1$ and an effect size (difference between the observed and the predicted percent-spliced-in, $|\Delta \psi|$ or between the observed and the predicted splicing efficiency, $|\Delta \theta|)$ larger than 0.3 .

\section{Detection of mono-allelic expression}

For mono-allelic expression analysis, only heterozygous single nucleotide variants from WES were considered. Reads assigned to each allele were counted using the ASEReadCounter function from GATK v4.0 (114). Positions with less than 10 reads in total were filtered out. Afterward, the negative binomial test described in Kremer et al. (23), was performed. This fully corresponds to the MAE module of DROP, v1.0.3.

\section{Association of outlier genes with WES rare variants}

Variants were grouped by predicted consequence in a similar way as done in Li et al. (62), but with some minor modifications. Specifically, the categorization was: splice: splice acceptor, splice donor, splice region; frameshift: frameshift, UTR: 3' UTR, 5' UTR, start lost; non-coding: 
medRxiv preprint doi: https://doi.org/10.1101/2021.04.01.21254633; this version posted May 16, 2021. The copyright holder for this preprint (which was not certified by peer review) is the author/funder, who has granted medRxiv a license to display the preprint in perpetuity. It is made available under a CC-BY-NC-ND 4.0 International license .

downstream, upstream, intron, regulatory region, intergenic; coding: coding, deletion, insertion, missense, stop lost; stop: stop gained; synonymous: synonymous, stop retained. Each sample-gene combination was categorized as overexpression, underexpression, or non-outlier according to the OUTRIDER results. Then, for each of them, we searched for a rare variant and assigned the variant's consequence group to it. A Fisher's exact test was performed for each variant group against each expression outlier class, thus obtaining a p-value. If rare variants from multiple groups were found on a sample-gene combination, the group with the lowest p-value (therefore highest association) was selected. Afterward, for each outlier class, the proportion of each group of rare variants was computed (e.g., \# of underexpression outliers with a rare stop variant / total \# of underexpression outliers). 95\% confidence intervals were obtained from a binomial test for all proportions. The procedure was repeated in a similar way for splicing outliers caused by aberrant percent-spliced-in. Only protein-coding genes were considered. Samples with more than 20 expression outlier genes were discarded for the expression analysis, and samples with more than 40 splicing outlier genes were discarded for the splicing analysis.

\section{Association of WES rare variants with outlier genes}

All rare variants in expressed protein-coding genes in autosomal chromosomes were considered. For each sample, each rare homozygous variant was matched with the corresponding outlier class (overexpression, underexpression, or non-outlier) of the gene where it is located. Then, for each group of rare variants, the proportion of each outlier class was computed (e.g., \# of rare stop variants in a gene that is an underexpression outlier / total \# of rare stop variants). Stop and frameshift variants that were in expressed positions and not in the last exon were marked as potential PTVs. The procedure was repeated in a similar way by associating rare variants with 
medRxiv preprint doi: https://doi.org/10.1101/2021.04.01.21254633; this version posted May 16, 2021. The copyright holder for this preprint (which was not certified by peer review) is the author/funder, who has granted medRxiv a license to display the preprint in perpetuity.

It is made available under a CC-BY-NC-ND 4.0 International license .

splicing outliers, but splitting the 'splice' category into 'splice site' (which includes both donor and acceptor dinucleotides) and 'splice region'.

MAE was tested on each rare heterozygous SNV in genes in autosomal chromosomes. Then, for each group of rare variants, the proportion of each MAE category (towards the reference or alternative allele, or none) was computed (e.g., \# of rare stop SNVs that are mono-allelically expressed towards the alternative allele / total \# of rare stop SNVs).

\section{Enrichment of gene classes}

We performed pairwise logistic regression where the response variable is the outlier class and the predictor the gene category. The odds ratio and 95\% confidence interval were derived from the estimates and standard errors of the coefficients.

\section{Lists of genes}

OMIM genes were downloaded from their portal (Online resources). Mitochondrial disease genes are our own expansion from the list shared in ref (31). Hematology, neurology, and ophthalmology genes were extracted from ref. (25), neuromuscular genes were taken from ref. (26), and skeletal dysplasia genes from ref. (28). Imprinted genes were taken from ref. (115). LoF intolerant genes correspond to the genes with a loss-of-function observed/expected upper bound fraction $<0.35$ from ref. (105).

\section{Online resources}

Code to reproduce the figures: https://github.com/gagneurlab/RNA diagnostics_paper_figures Pipeline to align and call WES/WGS variants: https://github.com/mri-ihg/ngs pipeline/ DROP, https://github.com/gagneurlab/drop

GATK best practices for RNAseq short variant discovery, https://gatk.broadinstitute.org/hc/en-us/articles/360035531192-RNAseq-short-variant-discovery$\underline{\text { SNPs-Indels- }}$ 
medRxiv preprint doi: https://doi.org/10.1101/2021.04.01.21254633; this version posted May 16, 2021. The copyright holder for this preprint (which was not certified by peer review) is the author/funder, who has granted medRxiv a license to display the preprint in perpetuity.

GTEx Portal, https://www.gtexportal.org/home/

MAJIQ, https://majiq.biociphers.org/

OMIM, www.omim.org

PAGE, https://page.ccm.sickkids.ca

\section{Supplementary Material}

fig. S1. Overview of the study.

fig. S2. Quality control.

fig. S3. DNA-RNA sample matching.

fig. S4. Aberrant events per sample.

fig. S5. Expression fold change.

fig. S6. Case with many mtDNA expression outliers.

fig. S7. Complex pattern of aberrant splicing.

fig. S8. Analysis on variants called by RNA-seq.

fig. S9. Rare variants leading to outliers.

fig. S10. Diagnostic rate across cohorts.

table S1: Sample annotation.

table S2: Summary of candidate genes pinpointed via RNA-seq

table S3. Summary of WES-diagnosed cases with an RNA-defect

\section{Declarations}

Ethics approval and consent to participate: All individuals included or their legal guardians provided written informed consent before evaluation, in agreement with the Declaration of Helsinki and approved by the ethical committee of the Technical University of Munich.

Consent for publication: Not applicable

Availability of data and materials: The datasets (privacy-preserving count matrices) supporting the conclusions of this article are available without restriction in the Zenodo repository, doi: 10.5281/zenodo.4646823 and 10.5281/zenodo.4646827. The necessary data and the code to reproduce the main figures are available in GitHub: https://github.com/gagneurlab/RNA_diagnostics_paper_figures. Due to data privacy policy, we cannot provide BAM or VCF files.

\section{Competing interests: none.}

Funding: The German Bundesministerium für Bildung und Forschung (BMBF) supported the study through the ERA PerMed project PerMiM (01KU2016A to VAY, HP, and JG), the Medical Informatics Initiative CORD-MI (Collaboration on Rare Diseases) to VAY, the project MechML (01IS18053F to MM), the German Network for Mitochondrial Disorders (mitoNET; 01GM1113C to HP), and the E-Rare project GENOMIT (01GM1207 to HP). MG was supported by the DZHG (German Centre for Cardiovascular Research). This study was funded by the 
medRxiv preprint doi: https://doi.org/10.1101/2021.04.01.21254633; this version posted May 16, 2021. The copyright holder for this preprint (which was not certified by peer review) is the author/funder, who has granted medRxiv a license to display the preprint in perpetuity. It is made available under a CC-BY-NC-ND 4.0 International license .

Deutsche Forschungsgemeinschaft (DFG, German Research Foundation) - NFDI 1/1 "GHGA German Human Genome-Phenome Archive”. The Bavaria California Technology Center supported CM through a fellowship. RWT is supported by the Wellcome Centre for Mitochondrial Research (203105/Z/16/Z), the Medical Research Council (MRC) International Centre for Genomic Medicine in Neuromuscular Disease (MR/S005021/1), the Mitochondrial Disease Patient Cohort (UK) (G0800674), the Lily Foundation and the UK NHS Specialised Commissioners who fund the "Rare Mitochondrial Disorders of Adults and Children" Service in Newcastle upon Tyne. CLA is supported by a National Institute for Health Research (NIHR) Post-Doctoral Fellowship (PDF-2018-11-ST2-021). This work was supported by the Practical Research Project for Rare/Intractable Diseases (JP20ek0109468, JP19ek0109273) from the Agency for Medical Research and Development (AMED), Japan. This research was supported by the Instituto de Salud Carlos III (PI16/01048; PI19/01310) (Co-funded by European Regional Development Fund "A way to make Europe") and the Centro de Investigación Biomédica en Red de Enfermedades Raras (CIBERER), an initiative of the Instituto de Salud Carlos III (Ministerio de Ciencia e Innovación, Spain). The present study was supported by the Departament de Salut, Generalitat de Catalunya (URDCAT project, SLT002/16/00174). This study was supported by the Agència de Gestió d'Ajuts Universitaris i de Recerca (AGAUR) (2017: SGR 1428) and the CERCA Programme/Generalitat de Catalunya. The Genotype-Tissue Expression (GTEx) Project was supported by the Common Fund of the Office of the Director of the National Institutes of Health, and by NCI, NHGRI, NHLBI, NIDA, NIMH, and NINDS. The data used for the analyses described in this manuscript were obtained from the GTEx Portal on June 12, 2017 , under accession number dbGaP: phs00424.v6.p1.

\section{Authors' contributions}

Conceptualization: JG, HP. Data Curation Management: VAY, MG, RK, AN. Formal Analysis: VAY, MG, RK, CM. Investigation: MG, RK, AN. Resources: CLA, SB, HB, EC, FD, FF, PF, DG, JH, SJH, MH, YSI, YK, TK, TDK, CL, DL, CCM, JAM, SM, GMP, KM, AO, YO, DPA, EP, ARi, ARo, JS, CS, RWT, CT, FT, RVC, AV, MW, SBW, MX. Software: VAY, CM, NHS, MFM, RB, TS. Supervision: JG, HP. Validation: MG, RK, SLS, HP. Visualization: VAY, MG, JG, HP. Writing - Original Draft Preparation: VAY, MG, JG, HP. Writing - Review \& Editing: all authors.

Acknowledgements: We are grateful to the patients, their families, and the referring clinicians for participation in the study. We thank the Sequencing Core Facility of the HelmholtzZentrum München for providing the sequencing service. Figure 1 was created with BioRender.com.
Abbreviations:
CAT: Clinically accessible tissue
EBV: Epstein-Barr virus
FDR: False discovery rate
LoF: Loss-of-function 
medRxiv preprint doi: https://doi.org/10.1101/2021.04.01.21254633; this version posted May 16, 2021. The copyright holder for this preprint (which was not certified by peer review) is the author/funder, who has granted medRxiv a license to display the preprint in perpetuity.

It is made available under a CC-BY-NC-ND 4.0 International license .

MAE: Mono-allelic expression

MNV: Multi-nucleotide variant

mtDNA: Mitochondrial DNA

NBPF: Neuroblastoma breakpoint family

NGS: Next generation sequencing

NMD: Nonsense-mediated decay

PTC: Premature termination codon

PTV: Protein-truncating variant

RNA-seq: RNA sequencing

SNV: Single nucleotide variant

UTR: Untranslated region

VEP: Variant effect predictor

VUS: Variant of uncertain significance

WES: Whole exome sequencing

WGS: Whole genome sequencing

Table 1. Summary of cases diagnosed via RNA-seq. AE: aberrant expression, AS: aberrant splicing, MAE: mono-allelic expression, Var: intronic variant detected via RNA-seq. The superscripts in certain patient ids correspond to the studies where they were published.

\begin{tabular}{|c|c|c|c|c|c|c|c|}
\hline Patient & Sex & $\begin{array}{c}\text { Age } \\
\text { range of } \\
\text { onset }\end{array}$ & Primary symptoms & $\begin{array}{c}\text { Genetic } \\
\text { diagnosis }\end{array}$ & Variants & $\begin{array}{l}\text { Variant } \\
\text { class }\end{array}$ & $\begin{array}{c}\text { RNA } \\
\text { defects }\end{array}$ \\
\hline \multirow[b]{2}{*}{$\mathrm{R} 62943^{59}$} & \multirow[b]{2}{*}{$F$} & \multirow[b]{2}{*}{ prenatal } & \multirow{2}{*}{$\begin{array}{l}\text { neurodevelopmental } \\
\text { delay, 3-MGA }\end{array}$} & C19orf70 & c.143 del & frameshift & \multirow[b]{2}{*}{$A E, A S$} \\
\hline & & & & NM_205767. & c. $29+272$ G>C & intronic & \\
\hline $\mathrm{R} 98254^{59}$ & $F$ & infant & \begin{tabular}{|l} 
Leigh syndrome, basal \\
ganglia abnormality on \\
MRI, \\
neurodevelopmental \\
delay, intellectual \\
disability, seizures, \\
encephalopathy, \\
brainstem abnormality \\
on MRI, complex I and \\
IV defects
\end{tabular} & $\begin{array}{c}\text { NM_032478. } \\
3\end{array}$ & c. $-174 \_-148$ del & $\begin{array}{c}\text { 5utr } \\
\text { deletion }\end{array}$ & $A E$ \\
\hline $\mathrm{R} 86287^{59}$ & M & infant & $\begin{array}{l}\text { hypotonia, } \\
\text { cardiomyopathy, white } \\
\text { matter abnormality on } \\
\text { MRI, elevated lactate, } \\
\text { complex I and IV defects }\end{array}$ & NM_018122. & \begin{tabular}{|c|}
$\mathrm{c} .492+2 \mathrm{~T}>\mathrm{C} ;$ \\
1: c. $228-20$ \\
$\mathrm{~T}>\mathrm{C}$ \\
$\mathrm{c} .228-12 \mathrm{C}>\mathrm{G} ;$ \\
1: c. $228-20$ \\
$\mathrm{~T}>\mathrm{C}$ \\
\end{tabular} & $\begin{array}{l}\text { splice } \\
\text { donor }\end{array}$ & AS \\
\hline
\end{tabular}




\begin{tabular}{|c|c|c|c|c|c|c|c|}
\hline \multirow[b]{2}{*}{$R 89912^{59}$} & \multirow[b]{2}{*}{ M } & \multirow[b]{2}{*}{ infant } & \multirow{2}{*}{$\begin{array}{l}\text { Leigh syndrome, basal } \\
\text { ganglia abnormality on } \\
\text { MRI, } \\
\text { neurodevelopmental } \\
\text { delay, speech delay, } \\
\text { intellectual disability, } \\
\text { encephalopathy, } \\
\text { hypotonia, nystagmus, } \\
\text { brainstem abnormality } \\
\text { on MRI, elevated lactate, } \\
\text { metabolic acidosis, } \\
\text { complex I defect }\end{array}$} & NFU1 & c. $362 \mathrm{~T}>\mathrm{C}$ & missense & \multirow[b]{2}{*}{$\begin{array}{l}\mathrm{AE} \\
\mathrm{MAE}\end{array}$} \\
\hline & & & & $\begin{array}{c}\text { NM_0010027 } \\
55.2\end{array}$ & $\begin{array}{c}\text { c. } 485-2588 \text { 54 } \\
5+1655 \mathrm{del}\end{array}$ & deletion & \\
\hline $\mathrm{R} 19100^{59}$ & M & child & $\begin{array}{lr}\text { myopathic } & \text { facies, } \\
\text { exercise } & \text { intolerance, } \\
\text { muscle } & \text { weakness, } \\
\text { motor, growth, speech } \\
\text { and neurodevelopmental } \\
\text { delay, intellectual } \\
\text { disability, microcephaly, } \\
\text { hypotonia, } \\
\text { cardiomyopathy, } \\
\text { dysmorphic features, } \\
\text { ragged red fibers, } \\
\text { elevated lactate r } \\
\end{array}$ & $\begin{array}{c}\text { NM_001151. } \\
3\end{array}$ & c. $598 \mathrm{G}>\mathrm{A}$ & $\begin{array}{l}\text { splice } \\
\text { region }\end{array}$ & $\mathrm{AE}$ \\
\hline $\mathrm{R} 15264^{23}$ & $\mathrm{~F}$ & infant & $\begin{array}{l}\text { muscle } \quad \text { weakness, } \\
\text { myopathy, } \quad \text { muscular } \\
\text { dystrophy, hypotonia }\end{array}$ & \begin{tabular}{|c|} 
TIMMDC1 \\
NM_016589. \\
3
\end{tabular} & $\begin{array}{c}c .596+2146 \\
A>G\end{array}$ & intronic & $\begin{array}{l}\mathrm{AE}, \mathrm{AS}, \\
\quad \operatorname{Var}\end{array}$ \\
\hline R36605 & M & infant & $\begin{array}{l}\text { acute liver failure, } \\
\text { hypotension of the } \\
\text { muscles, hypertension of } \\
\text { the limbs, intermittent } \\
\text { deficiency of motor } \\
\text { function of the pupil, } \\
\text { delayed light reaction } \\
\text { and nystagmus }\end{array}$ & $\begin{array}{c}\text { NM_0011638 } \\
12.1\end{array}$ & c. $1302 \mathrm{C}>\mathrm{G}$ & $\begin{array}{c}\text { synonymo } \\
\text { us }\end{array}$ & $A E, A S$ \\
\hline R61100 & $\mathrm{F}$ & infant & $\begin{array}{l}\text { encephalopathy, } \\
\text { respiratory distress }\end{array}$ & \begin{tabular}{|c|} 
NAXE \\
NM_144772. \\
2
\end{tabular} & c. $292-12$ C>G & intron & $A E, A S$ \\
\hline R77611 & & infant & recurrent acute liver & $D L D$ & c. $685 \mathrm{G}>\mathrm{T}$ & missense & $\begin{array}{l}\mathrm{AE}, \\
\mathrm{MAE}\end{array}$ \\
\hline R/18011 & $r$ & Intant & failure & $\begin{array}{c}\text { NM_000108. } \\
3\end{array}$ & Not detected & & \\
\hline & & & motor and & MRPS25 & & & \\
\hline $\mathrm{R} 16472^{59}$ & $M$ & child & $\begin{array}{ll}\text { neurodevelopmental } \\
\text { delay, } & \text { respiratory }\end{array}$ & NM_022497. & c. $329+75 \mathrm{G}>\mathrm{A}$ & intronic & $\begin{array}{c}\text { AL, AS, } \\
\text { Var }\end{array}$ \\
\hline
\end{tabular}




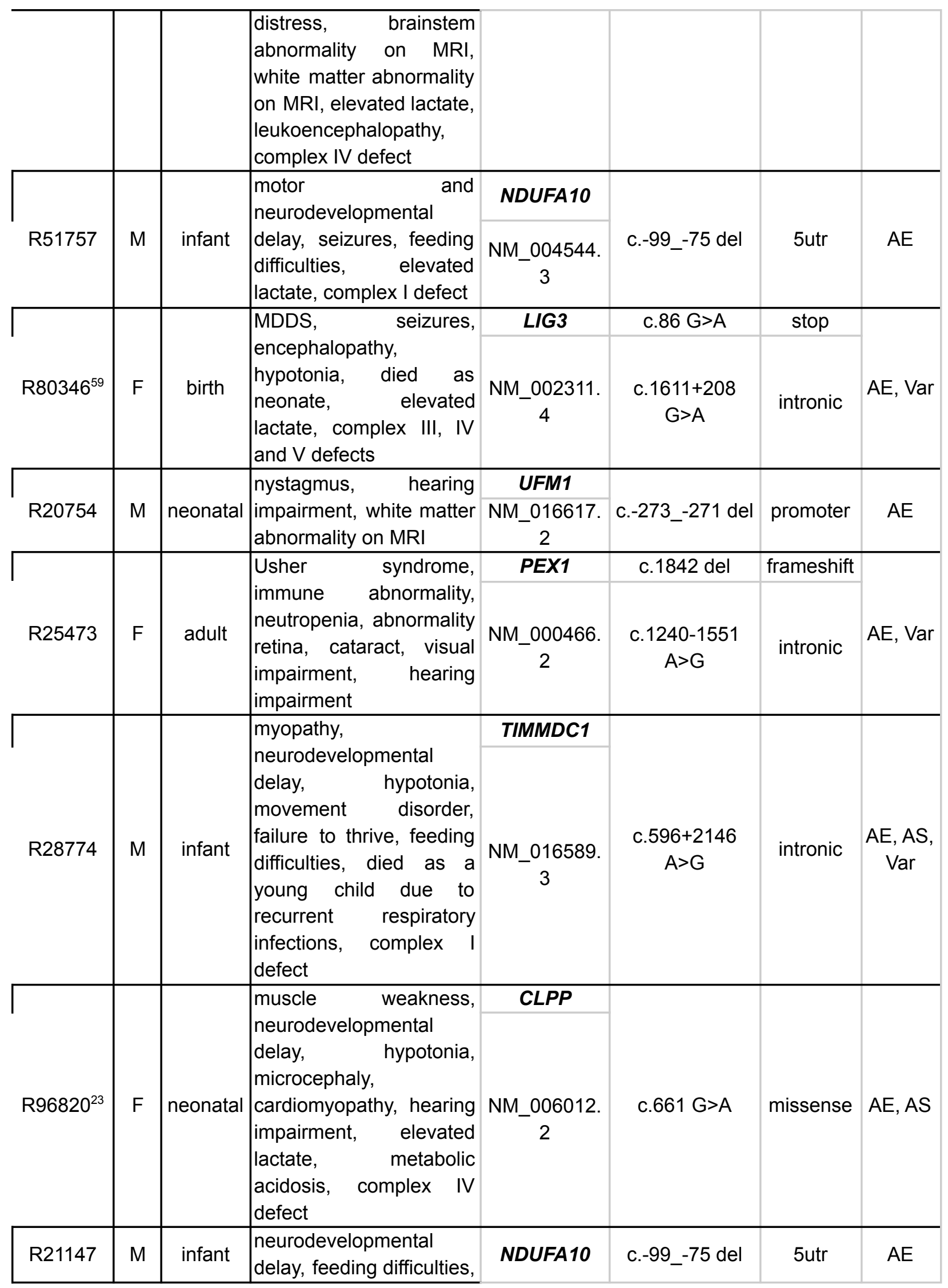


medRxiv preprint doi: https://doi.org/10.1101/2021.04.01.21254633; this version posted May 16, 2021. The copyright holder for this preprint (which was not certified by peer review) is the author/funder, who has granted medRxiv a license to display the preprint in perpetuity.

It is made available under a CC-BY-NC-ND 4.0 International license .

\begin{tabular}{|c|c|c|c|c|c|c|c|}
\hline & & & \begin{tabular}{|ll} 
elevated lactate, & lamplex I defect
\end{tabular} & $\begin{array}{c}\text { NM_004544. } \\
3\end{array}$ & & & \\
\hline \multirow[b]{2}{*}{$\mathrm{R} 64921^{23}$} & \multirow[b]{2}{*}{ M } & \multirow[b]{2}{*}{ child } & \multirow[b]{2}{*}{$\begin{array}{l}\text { ophthalmoplegia, speech } \\
\text { delay, developmental } \\
\text { regression, ataxia, } \\
\text { abnormality retina, visual } \\
\text { impairment, complex I } \\
\text { defect }\end{array}$} & MCOLN1 & c. $681-19 A>C$ & intronic & \multirow[b]{2}{*}{$A E, A S$} \\
\hline & & & & $\begin{array}{c}\text { NM_020533. } \\
2\end{array}$ & c. $832 C>T$ & stop & \\
\hline R52016 23 & M & infant & \begin{tabular}{|lr} 
died as infant, basal \\
ganglia abnormality on \\
MRI, \\
neurodevelopmental \\
delay, encephalopathy, \\
hypotonia, myoclonus, \\
nystagmus, abnormality \\
eye & movement, \\
neuropathy, brainstem \\
abnormality on MRI, \\
elevated lactate, \\
complex I defect
\end{tabular} & $\begin{array}{c}\text { NM_016589. } \\
3\end{array}$ & $\begin{array}{c}c .596+2146 \\
A>G\end{array}$ & intronic & $\begin{array}{c}\text { AE, AS, } \\
\text { Var }\end{array}$ \\
\hline \multirow[b]{2}{*}{ R46723 } & \multirow[b]{2}{*}{$\mathrm{F}$} & \multirow[b]{2}{*}{ infant } & \multirow{2}{*}{$\begin{array}{l}\text { basal ganglia } \\
\text { abnormality on MRI, } \\
\text { encephalopathy, } \\
\text { brainstem abnormality } \\
\text { on MRI, complex I defect }\end{array}$} & NDUFAF5 & c. $2 \mathrm{~T}>\mathrm{C}$ & start-loss & \multirow[b]{2}{*}{$\begin{array}{c}\text { AE, AS, } \\
\text { Var }\end{array}$} \\
\hline & & & & $\begin{array}{c}\text { NM_024120. } \\
4\end{array}$ & c.223-907 A >C & intronic & \\
\hline \multirow[b]{2}{*}{$R 58859^{56}$} & \multirow[b]{2}{*}{ M } & \multirow[b]{2}{*}{ adult } & \multirow{2}{*}{$\begin{array}{|lr|}\text { ophthalmoplegia, } \\
\text { myopathic racies, } \\
\text { myalgia, } & \text { diabetes, } \\
\text { arrhythmias } & \end{array}$} & TAZ & & & \multirow[b]{2}{*}{ AS } \\
\hline & & & & NM_181313 & c. $348 \mathrm{C}>\mathrm{T}$ & $\begin{array}{c}\text { synonymo } \\
\text { us }\end{array}$ & \\
\hline \multirow[b]{2}{*}{$\mathrm{R} 80184^{23}$} & \multirow[b]{2}{*}{$\mathrm{M}$} & \multirow[b]{2}{*}{ prenatal } & \multirow[b]{2}{*}{ 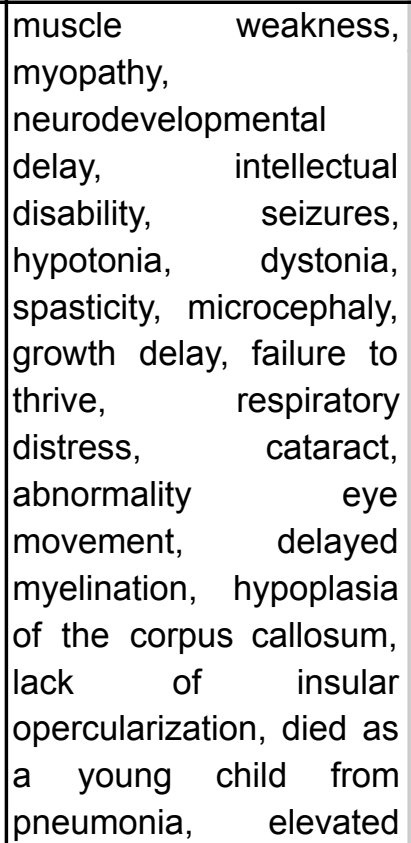 } & ALDH18A1 & c.1982 C>A & stop & \\
\hline & & & & $\begin{array}{c}\text { NM_0010174 } \\
23.1\end{array}$ & C.1858 C>T & missense & $\begin{array}{l}\text { AE, } \\
\text { MAE }\end{array}$ \\
\hline
\end{tabular}




\begin{tabular}{|c|c|c|c|c|c|c|c|}
\hline & & & $\begin{array}{l}\text { lactate, complex I and } \\
\text { I/III defects }\end{array}$ & & & & \\
\hline R59185 & $\mathrm{F}$ & child & 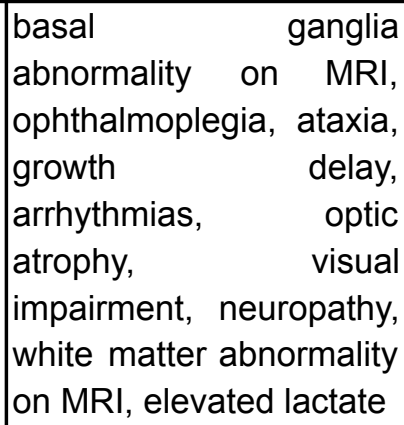 & $\begin{array}{c}\text { NM_002495. } \\
2\end{array}$ & c.466_469 dup & frameshift & $\mathrm{AE}$ \\
\hline $\mathrm{R} 63087^{58}$ & $M$ & child & $\begin{array}{l}\text { basal ganglia } \\
\text { abnormality on MRI, } \\
\text { muscle weakness, } \\
\text { myopathy, } \\
\text { rhabdomyolysis, } \\
\text { neurodevelopmental } \\
\text { delay, seizures, infection } \\
\text { related deterioration, } \\
\text { elevated lactate }\end{array}$ & $\begin{array}{c}\text { NM_178526. } \\
4\end{array}$ & c. $380+2 \mathrm{~T}>\mathrm{A}$ & $\begin{array}{l}\text { splice } \\
\text { donor }\end{array}$ & AS \\
\hline$R 44456^{59}$ & $\mathrm{~F}$ & infant & $\begin{array}{lr}\text { MADD, } & \text { respiratory } \\
\text { distress, } & \text { dysmorphic } \\
\text { features } & \\
\end{array}$ & $\begin{array}{c}\text { MRPL44 } \\
\text { NM_022915. } \\
3 \\
\end{array}$ & c. $179+3 A>G$ & $\begin{array}{l}\text { splice } \\
\text { region }\end{array}$ & $\mathrm{AE}, \mathrm{AS}$ \\
\hline & & & & NDUFAF5 & c.605 dup & frameshift & \\
\hline R33391 & $\mathrm{F}$ & infant & lactate, complex I defect & $\begin{array}{c}\text { NM_024120. } \\
4\end{array}$ & c.223-907 A>C & intronic & AS, Var \\
\hline R66696 & $M$ & $\begin{array}{l}\text { young } \\
\text { child }\end{array}$ & $\begin{array}{l}\text { muscle weakness, } \\
\text { myopathy, } \\
\text { rhabdomyolysis, } \\
\text { infection related } \\
\text { deterioration, died as } \\
\text { child, complex I, III and } \\
\text { IV defects }\end{array}$ & $\begin{array}{c}\text { NM_0012614 } \\
27.1\end{array}$ & $\begin{array}{c}\text { c.2550-865_26 } \\
\text { 67-34 del }\end{array}$ & deletion & AS \\
\hline R24289 & $M$ & $\begin{array}{l}\text { young } \\
\text { child }\end{array}$ & $\begin{array}{l}\text { hypotonia, } \\
\text { developmental delay, } \\
\text { hearing impairment, } \\
\text { white matter abnormality } \\
\text { on MRI, lactic acidemia, } \\
\text { hyperlactacidemia, } \\
\text { proteinuria, glycosuria }\end{array}$ & $\begin{array}{c}\text { NM_015713. } \\
4\end{array}$ & c. $328 \mathrm{C}>\mathrm{T}$ & missense & $\begin{array}{l}\text { AE, } \\
\text { MAE }\end{array}$ \\
\hline R98349 & $F$ & infant & $\begin{array}{l}\text { clotting defect, lactic } \\
\text { acidosis }\end{array}$ & $\begin{array}{c}\boldsymbol{D L D} \\
\mathrm{NM} 000108 . \\
5 \\
\end{array}$ & $\begin{array}{c}c .685 \mathrm{G}>\mathrm{T} \\
\text { c. } 1046+5 \mathrm{G}>\mathrm{T}\end{array}$ & \begin{tabular}{|c|} 
missense \\
splice \\
region \\
\end{tabular} & AS \\
\hline $\mathrm{R} 91273^{59}$ & $\mathrm{~F}$ & adult & MADD during pregnancy & $\begin{array}{c}\text { ETFDH } \\
\text { NM_004453. } \\
3 \\
\end{array}$ & c.687_688 del & frameshift & $\mathrm{AE}$ \\
\hline
\end{tabular}


medRxiv preprint doi: https://doi.org/10.1101/2021.04.01.21254633; this version posted May 16, 2021. The copyright holder for this preprint (which was not certified by peer review) is the author/funder, who has granted medRxiv a license to display the preprint in perpetuity. It is made available under a CC-BY-NC-ND 4.0 International license .

\begin{tabular}{|c|c|c|c|c|c|c|c|}
\hline R60537 & $\mathrm{M}$ & neonatal & $\begin{array}{l}\text { congenital disorder of } \\
\text { glycosylation, seizures, } \\
\text { cognitive impairment, } \\
\text { nose abnormalities, large } \\
\text { fleshy ears, abnormal } \\
\text { isoelectric focusing of } \\
\text { serum transferrin }\end{array}$ & NM_00183.4 & c. $291-135$ C>T & intronic & $\mathrm{AE}$, Var \\
\hline \multirow[b]{2}{*}{ R70961 } & \multirow[b]{2}{*}{$M$} & \multirow[b]{2}{*}{$\begin{array}{l}\text { young } \\
\text { child }\end{array}$} & \multirow{2}{*}{$\begin{array}{l}\text { Leigh syndrome, optic } \\
\text { atrophy, parkinsonism, } \\
\text { status epilepticus, } \\
\text { developmental } \\
\text { regression, abnormal } \\
\text { thalamic size, lactic } \\
\text { acidosis, urinary } \\
\text { glycosaminoglycan } \\
\text { excretion }\end{array}$} & PTCD3 & c. $1519-1 \mathrm{G}>\mathrm{C}$ & $\begin{array}{c}\text { splice } \\
\text { acceptor }\end{array}$ & \\
\hline & & & & NM_017952 & c. 1918 C>G & missense & AS \\
\hline
\end{tabular}

\section{References}

1. Nguengang Wakap S, Lambert DM, Olry A, Rodwell C, Gueydan C, Lanneau V, et al. Estimating cumulative point prevalence of rare diseases: analysis of the Orphanet database. Eur J Hum Genet EJHG. 2019/09/16 ed. 2020 Feb;28(2):165-73.

2. EURORDIS. Rare Diseases: Understanding this Public Health Priority. Rare Dis. 2005;14.

3. Wright CF, FitzPatrick DR, Firth HV. Paediatric genomics: diagnosing rare disease in children. Nat Rev Genet. 2018 May;19(5):253-68.

4. Repp BM, Mastantuono E, Alston CL, Schiff M, Haack TB, Rötig A, et al. Clinical, biochemical and genetic spectrum of 70 patients with ACAD9 deficiency: is riboflavin supplementation effective? Orphanet J Rare Dis. 2018;13(1):120.

5. Koch J, Mayr JA, Alhaddad B, Rauscher C, Bierau J, Kovacs-Nagy R, et al. CAD mutations and uridine-responsive epileptic encephalopathy. Brain. 2017

Feb;140(2):279-86.

6. Boycott KM, Rath A, Chong JX, Hartley T, Alkuraya FS, Baynam G, et al. International Cooperation to Enable the Diagnosis of All Rare Genetic Diseases. Am J Hum Genet. 2017 May;100(5):695-705.

7. Wortmann S, Mayr J, Nuoffer J, Prokisch H, Sperl W. A Guideline for the Diagnosis of Pediatric Mitochondrial Disease: The Value of Muscle and Skin Biopsies in the Genetics Era. Neuropediatrics. 2017 Aug;48(04):309-14.

8. Wright CF, McRae JF, Clayton S, Gallone G, Aitken S, FitzGerald TW, et al. Making new genetic diagnoses with old data: iterative reanalysis and reporting from genome-wide data in 1,133 families with developmental disorders. Genet Med. 2018 Oct;20(10):1216-23.

9. Yang Y, Muzny DM, Reid JG, Bainbridge MN, Willis A, Ward PA, et al. Clinical Whole-Exome Sequencing for the Diagnosis of Mendelian Disorders. N Engl J Med. 2013 Oct 17;369(16):1502-11.

10. Farwell KD, Shahmirzadi L, El-Khechen D, Powis Z, Chao EC, Tippin Davis B, et al. Enhanced utility of family-centered diagnostic exome sequencing with inheritance 
medRxiv preprint doi: https://doi.org/10.1101/2021.04.01.21254633; this version posted May 16, 2021. The copyright holder for this preprint

(which was not certified by peer review) is the author/funder, who has granted medRxiv a license to display the preprint in perpetuity.

It is made available under a CC-BY-NC-ND 4.0 International license .

model-based analysis: results from 500 unselected families with undiagnosed genetic conditions. Genet Med. 2015 Jul;17(7):578-86.

11. Stark Z, Tan TY, Chong B, Brett GR, Walsh M, Peters H, et al. A prospective evaluation of whole-exome sequencing as a first-tier molecular test in infants with suspected monogenic disorders. Genet Med. 2016 Nov;18(11):1090-6.

12. Retterer K, Juusola J, Cho MT, Vitazka P, Millan F, Gibellini F, et al. Clinical application of whole-exome sequencing across clinical indications. Genet Med. 2016 Jul;18(7):696-704.

13. Clark MM, Stark Z, Farnaes L, Tan TY, White SM, Dimmock D, et al. Meta-analysis of the diagnostic and clinical utility of genome and exome sequencing and chromosomal microarray in children with suspected genetic diseases. Genomic Med Res. 2018 May $10 ; 3(16)$.

14. Mattick JS, Dinger M, Schonrock N, Cowley M. Whole genome sequencing provides better diagnostic yield and future value than whole exome sequencing. Med J Aust. 2018 Sep;209(5):197-9.

15. Boycott KM, Ardigó D. Addressing challenges in the diagnosis and treatment of rare genetic diseases. Nat Rev Drug Discov. 2018 Mar;17(3):151-2.

16. McLaren W, Gil L, Hunt SE, Riat HS, Ritchie GRS, Thormann A, et al. The Ensembl Variant Effect Predictor. Genome Biol. 2016 Dec;17(1):122.

17. Stenson PD, Mort M, Ball EV, Evans K, Hayden M, Heywood S, et al. The Human Gene Mutation Database: towards a comprehensive repository of inherited mutation data for medical research, genetic diagnosis and next-generation sequencing studies. Hum Genet. 2017 Jun;136(6):665-77.

18. Ma M, Ru Y, Chuang L-S, Hsu N-Y, Shi L-S, Hakenberg J, et al. Disease-associated variants in different categories of disease located in distinct regulatory elements. BMC Genomics. 2015;16(Suppl 8):S3.

19. Soemedi R, Cygan KJ, Rhine CL, Wang J, Bulacan C, Yang J, et al. Pathogenic variants that alter protein code often disrupt splicing. Nat Genet. 2017 Jun;49(6):848-55.

20. Cheung R, Insigne KD, Yao D, Burghard CP, Wang J, Hsiao Y-HE, et al. A Multiplexed Assay for Exon Recognition Reveals that an Unappreciated Fraction of Rare Genetic Variants Cause Large-Effect Splicing Disruptions. Mol Cell. 2019 Jan;73(1):183-194.e8.

21. Richards S, Aziz N, Bale S, Bick D, Das S, Gastier-Foster J, et al. Standards and guidelines for the interpretation of sequence variants: a joint consensus recommendation of the American College of Medical Genetics and Genomics and the Association for Molecular Pathology. Genet Med. 2015 May;17(5):405-23.

22. Truty R, Ouyang K, Rojahn S, Garcia S, Colavin A, Hamlington B, et al. Spectrum of splicing variants in disease genes and the ability of RNA analysis to reduce uncertainty in clinical interpretation. Am J Hum Genet. 2021 Apr;108(4):696-708.

23. Kremer LS, Bader DM, Mertes C, Kopajtich R, Pichler G, Iuso A, et al. Genetic diagnosis of Mendelian disorders via RNA sequencing. Nat Commun. 2017 Aug;8(1):15824.

24. Cummings BB, Marshall JL, Tukiainen T, Lek M, Donkervoort S, Foley AR, et al. Improving genetic diagnosis in Mendelian disease with transcriptome sequencing. Sci Transl Med. 2017;9(386):eaal5209.

25. Frésard L, Smail C, Ferraro NM, Teran NA, Li X, Smith KS, et al. Identification of rare-disease genes using blood transcriptome sequencing and large control cohorts. Nat 
medRxiv preprint doi: https://doi.org/10.1101/2021.04.01.21254633; this version posted May 16, 2021. The copyright holder for this preprint

(which was not certified by peer review) is the author/funder, who has granted medRxiv a license to display the preprint in perpetuity.

It is made available under a CC-BY-NC-ND 4.0 International license .

Med. 2019 Jun;25(6):911-9.

26. Gonorazky HD, Naumenko S, Ramani AK, Nelakuditi V, Mashouri P, Wang P, et al. Expanding the Boundaries of RNA Sequencing as a Diagnostic Tool for Rare Mendelian Disease. Am J Hum Genet. 2019 Mar;104(3):466-83.

27. Lee H, Huang AY, Wang L, Yoon AJ, Renteria G, Eskin A, et al. Diagnostic utility of transcriptome sequencing for rare Mendelian diseases. Genet Med. 2019 Oct 14;22(3):490-9.

28. Murdock DR, Dai H, Burrage LC, Rosenfeld JA, Ketkar S, Müller MF, et al. Transcriptome-directed analysis for Mendelian disease diagnosis overcomes limitations of conventional genomic testing. J Clin Invest. 2021 Jan 4;131(1):e141500.

29. Havens MA, Duelli DM, Hastings ML. Targeting RNA splicing for disease therapy: RNA splicing for disease therapy. Wiley Interdiscip Rev RNA. 2013 May;4(3):247-66.

30. Yépez VA, Mertes C, Müller MF, Klaproth-Andrade D, Wachutka L, Frésard L, et al. Detection of aberrant gene expression events in RNA sequencing data. Nat Protoc. 2021 Feb;16(2):1276-96.

31. Stenton SL, Prokisch H. Genetics of mitochondrial diseases: Identifying mutations to help diagnosis. EBioMedicine. 2020 Jun;56:102784.

32. Haack TB, Haberberger B, Frisch E-M, Wieland T, Iuso A, Gorza M, et al. Molecular diagnosis in mitochondrial complex I deficiency using exome sequencing. J Med Genet. 2012 Apr;49(4):277-83.

33. Kopajtich R, Nicholls TJ, Rorbach J, Metodiev MD, Freisinger P, Mandel H, et al. Mutations in GTPBP3 Cause a Mitochondrial Translation Defect Associated with Hypertrophic Cardiomyopathy, Lactic Acidosis, and Encephalopathy. Am J Hum Genet. 2014 Dec;95(6):708-20.

34. Kornblum C, Nicholls TJ, Haack TB, Schöler S, Peeva V, Danhauser K, et al. Loss-of-function mutations in MGME1 impair mtDNA replication and cause multisystemic mitochondrial disease. Nat Genet. 2013 Feb;45(2):214-9.

35. Punzi G, Porcelli V, Ruggiu M, Hossain F, Menga A, Scarcia P, et al. SLC25A10 biallelic mutations in intractable epileptic encephalopathy with complex I deficiency. Hum Mol Genet. 2017 Nov 29;27(3):499-504.

36. Synofzik M, Haack TB, Kopajtich R, Gorza M, Rapaport D, Greiner M, et al. Absence of BiP Co-chaperone DNAJC3 Causes Diabetes Mellitus and Multisystemic Neurodegeneration. Am J Hum Genet. 2014 Dec;95(6):689-97.

37. Haack TB, Staufner C, Köpke MG, Straub BK, Kölker S, Thiel C, et al. Biallelic Mutations in NBAS Cause Recurrent Acute Liver Failure with Onset in Infancy. Am J Hum Genet. 2015 Jul;97(1):163-9.

38. Haack TB, Kopajtich R, Freisinger P, Wieland T, Rorbach J, Nicholls TJ, et al. ELAC2 Mutations Cause a Mitochondrial RNA Processing Defect Associated with Hypertrophic Cardiomyopathy. Am J Hum Genet. 2013 Aug 8;93:211-23.

39. Ait-El-Mkadem S, Dayem-Quere M, Gusic M, Chaussenot A, Bannwarth S, François B, et al. Mutations in MDH2, Encoding a Krebs Cycle Enzyme, Cause Early-Onset Severe Encephalopathy. Am J Hum Genet. 2017 Jan;100(1):151-9.

40. Mercati O, Abi Warde M-T, Lina-Granade G, Rio M, Heide S, de Lonlay P, et al. PRPS1 loss-of-function variants, from isolated hearing loss to severe congenital encephalopathy: New cases and literature review. Eur J Med Genet. 2020 Nov;63(11):104033. 
medRxiv preprint doi: https://doi.org/10.1101/2021.04.01.21254633; this version posted May 16, 2021. The copyright holder for this preprint

(which was not certified by peer review) is the author/funder, who has granted medRxiv a license to display the preprint in perpetuity.

It is made available under a CC-BY-NC-ND 4.0 International license .

41. Oláhová M, Hardy SA, Hall J, Yarham JW, Haack TB, Wilson WC, et al. LRPPRC mutations cause early-onset multisystem mitochondrial disease outside of the French-Canadian population. Brain. 2015 Dec;138(12):3503-19.

42. Kremer LS, L'hermitte-Stead C, Lesimple P, Gilleron M, Filaut S, Jardel C, et al. Severe respiratory complex III defect prevents liver adaptation to prolonged fasting. J Hepatol. 2016 Aug;65(2):377-85.

43. Kennedy H, Haack TB, Hartill V, Mataković L, Baumgartner ER, Potter H, et al. Sudden Cardiac Death Due to Deficiency of the Mitochondrial Inorganic Pyrophosphatase PPA2. Am J Hum Genet. 2016 Sep 1;99:674-82.

44. Gusic M, Schottmann G, Feichtinger RG, Du C, Scholz C, Wagner M, et al. Bi-Allelic UQCRFS1 Variants Are Associated with Mitochondrial Complex III Deficiency, Cardiomyopathy, and Alopecia Totalis. Am J Hum Genet. 2020 Jan;106(1):102-11.

45. Schneeberger PE, Bierhals T, Neu A, Hempel M, Kutsche K. de novo MEPCE nonsense variant associated with a neurodevelopmental disorder causes disintegration of 7SK snRNP and enhanced RNA polymerase II activation. Sci Rep. 2019 Dec;9(1):12516.

46. Wagner M, Osborn DPS, Gehweiler I, Nagel M, Ulmer U, Bakhtiari S, et al. Bi-allelic variants in RNF170 are associated with hereditary spastic paraplegia. Nat Commun. 2019 Dec;10(1):4790.

47. Huemer M, Karall D, Schossig A, Abdenur JE, Al Jasmi F, Biagosch C, et al. Clinical, morphological, biochemical, imaging and outcome parameters in 21 individuals with mitochondrial maintenance defect related to FBXL4 mutations. J Inherit Metab Dis. 2015 Sep;38(5):905-14.

48. Kopajtich R, Murayama K, Janecke AR, Haack TB, Breuer M, Knisely AS, et al. Biallelic IARS Mutations Cause Growth Retardation with Prenatal Onset, Intellectual Disability, Muscular Hypotonia, and Infantile Hepatopathy. Am J Hum Genet. 2016 Aug;99(2):414-22.

49. Van Haute L, Dietmann S, Kremer L, Hussain S, Pearce SF, Powell CA, et al. Deficient methylation and formylation of mt-tRNAMet wobble cytosine in a patient carrying mutations in NSUN3. Nat Commun. 2016 Nov;7(1):12039.

50. Hildick-Smith GJ, Cooney JD, Garone C, Kremer LS, Haack TB, Thon JN, et al. Macrocytic Anemia and Mitochondriopathy Resulting from a Defect in Sideroflexin 4. Am J Hum Genet. 2013 Nov;93(5):906-14.

51. Del Dotto V, Ullah F, Di Meo I, Magini P, Gusic M, Maresca A, et al. SSBP1 mutations cause mtDNA depletion underlying a complex optic atrophy disorder. J Clin Invest. 2019 Nov 18;130(1):108-25.

52. Powell CA, Kopajtich R, D’Souza AR, Rorbach J, Kremer LS, Husain RA, et al. TRMT5 Mutations Cause a Defect in Post-transcriptional Modification of Mitochondrial tRNA Associated with Multiple Respiratory-Chain Deficiencies. Am J Hum Genet. 2015 Aug;97(2):319-28.

53. Iuso A, Wiersma M, Schüller H-J, Pode-Shakked B, Marek-Yagel D, Grigat M, et al. Mutations in PPCS, Encoding Phosphopantothenoylcysteine Synthetase, Cause Autosomal-Recessive Dilated Cardiomyopathy. Am J Hum Genet. 2018 Jun;102(6):1018-30.

54. DeLuca DS, Levin JZ, Sivachenko A, Fennell T, Nazaire M-D, Williams C, et al. RNA-SeQC: RNA-seq metrics for quality control and process optimization. 
medRxiv preprint doi: https://doi.org/10.1101/2021.04.01.21254633; this version posted May 16, 2021. The copyright holder for this preprint

(which was not certified by peer review) is the author/funder, who has granted medRxiv a license to display the preprint in perpetuity.

It is made available under a CC-BY-NC-ND 4.0 International license .

Bioinformatics. 2012 Jun 1;28(11):1530-2.

55. Brechtmann F, Mertes C, Matusevičiūtė A, Yépez VA, Avsec Ž, Herzog M, et al. OUTRIDER: A Statistical Method for Detecting Aberrantly Expressed Genes in RNA Sequencing Data. Am J Hum Genet. 2018 Dec;103(6):907-17.

56. Mertes C, Scheller IF, Yépez VA, Çelik MH, Liang Y, Kremer LS, et al. Detection of aberrant splicing events in RNA-seq data using FRASER. Nat Commun. 2021 Dec;12(1):529.

57. Amberger JS, Bocchini CA, Scott AF, Hamosh A. OMIM.org: leveraging knowledge across phenotype-gene relationships. Nucleic Acids Res. 2019 Jan 8;47(D1):D1038-43.

58. Iuso A, Alhaddad B, Weigel C, Kotzaeridou U, Mastantuono E, Schwarzmayr T, et al. A Homozygous Splice Site Mutation in SLC25A42, Encoding the Mitochondrial Transporter of Coenzyme A, Causes Metabolic Crises and Epileptic Encephalopathy. Morava E, Baumgartner M, Patterson M, Rahman S, Zschocke J, Peters V, editors. JIMD Rep Vol 44. 2018;44:1-7.

59. Kopajtich R, Smirnov D, Stenton SL, Loipfinger S, Meng C, Scheller I, et al. Integration of proteomics with genomics and transcriptomics increases the diagnostic rate of Mendelian disorders [Internet]. Genetic and Genomic Medicine; 2021 Mar [cited 2021 Mar 13]. Available from: http://medrxiv.org/lookup/doi/10.1101/2021.03.09.21253187

60. Ferraro NM, Strober BJ, Einson J, Abell NS, Aguet F, Barbeira AN, et al. Transcriptomic signatures across human tissues identify functional rare genetic variation. Science. 2020 Sep 11;369(6509):eaaz5900.

61. Rivas MA, Pirinen M, Conrad DF, Lek M, Tsang EK, Karczewski KJ, et al. Effect of predicted protein-truncating genetic variants on the human transcriptome. Science. 2015 May 8;348(6235):666-9.

62. Li X, Kim Y, Tsang EK, Davis JR, Damani FN, Chiang C, et al. The impact of rare variation on gene expression across tissues. Nature. 2017 Oct;550(7675):239-43.

63. Bonder MJ, Smail C, Gloudemans MJ, Frésard L, Jakubosky D, D’Antonio M, et al. Identification of rare and common regulatory variants in pluripotent cells using population-scale transcriptomics. Nat Genet. 2021 Mar 4;25.

64. Hamilton EMC, Bertini E, Kalaydjieva L, Morar B, Dojčáková D, Liu J, et al. UFMI founder mutation in the Roma population causes recessive variant of H-ABC. Neurology. 2017 Oct 24;89(17):1821-8.

65. Sasarman F, Brunel-Guitton C, Antonicka H, Wai T, Shoubridge EA, LSFC Consortium. LRPPRC and SLIRP Interact in a Ribonucleoprotein Complex That Regulates Posttranscriptional Gene Expression in Mitochondria. Fox TD, editor. Mol Biol Cell. 2010 Apr 15;21(8):1315-23.

66. Wang Y, Ma M, Xiao X, Wang Z. Intronic splicing enhancers, cognate splicing factors and context-dependent regulation rules. Nat Struct Mol Biol. 2012 Oct;19(10):1044-52.

67. Pervouchine DD, Knowles DG, Guigo R. Intron-centric estimation of alternative splicing from RNA-seq data. Bioinformatics. 2013 Jan 15;29(2):273-4.

68. Ricard-Blum S. The Collagen Family. Cold Spring Harb Perspect Biol. 2011 Jan 1;3(1):a004978-a004978.

69. Vandepoele K, Van Roy N, Staes K, Speleman F, van Roy F. A Novel Gene Family NBPF: Intricate Structure Generated by Gene Duplications During Primate Evolution. Mol Biol Evol. 2005 Nov 1;22(11):2265-74. 
medRxiv preprint doi: https://doi.org/10.1101/2021.04.01.21254633; this version posted May 16, 2021. The copyright holder for this preprint

(which was not certified by peer review) is the author/funder, who has granted medRxiv a license to display the preprint in perpetuity.

It is made available under a CC-BY-NC-ND 4.0 International license .

70. Milenkovic D, Matic S, Kuhl I, Ruzzenente B, Freyer C, Jemt E, et al. TWINKLE is an essential mitochondrial helicase required for synthesis of nascent D-loop strands and complete mtDNA replication. Hum Mol Genet. 2013 May 15;22(10):1983-93.

71. El-Hattab AW, Craigen WJ, Scaglia F. Mitochondrial DNA maintenance defects. Biochim Biophys Acta BBA - Mol Basis Dis. 2017 Jun;1863(6):1539-55.

72. Desmet F-O, Hamroun D, Lalande M, Collod-Béroud G, Claustres M, Béroud C. Human Splicing Finder: an online bioinformatics tool to predict splicing signals. Nucleic Acids Res. 2009 May;37(9):e67-e67.

73. Lykke-Andersen S, Jensen TH. Nonsense-mediated mRNA decay: an intricate machinery that shapes transcriptomes. Nat Rev Mol Cell Biol. 2015 Nov;16(11):665-77.

74. Ferguson-Smith AC. Genomic imprinting: the emergence of an epigenetic paradigm. Nat Rev Genet. 2011 Aug;12(8):565-75.

75. Melber A, Na U, Vashisht A, Weiler BD, Lill R, Wohlschlegel JA, et al. Role of Nfu1 and Bol3 in iron-sulfur cluster transfer to mitochondrial clients. eLife. 2016 Aug 17;5:e15991.

76. Uzarska MA, Nasta V, Weiler BD, Spantgar F, Ciofi-Baffoni S, Saviello MR, et al. Mitochondrial Bol1 and Bol3 function as assembly factors for specific iron-sulfur proteins. eLife. 2016 Aug 17;5:e16673.

77. Ahting U, Mayr JA, Vanlander AV, Hardy SA, Santra S, Makowski C, et al. Clinical, biochemical, and genetic spectrum of seven patients with NFU1 deficiency. Front Genet. 2015 Apr 13;6:123.

78. Navarro-Sastre A, Tort F, Stehling O, Uzarska MA, Arranz JA, del Toro M, et al. A Fatal Mitochondrial Disease Is Associated with Defective NFU1 Function in the Maturation of a Subset of Mitochondrial Fe-S Proteins. Am J Hum Genet. 2011 Nov 11;89(5):656-67.

79. Kohda M, Tokuzawa Y, Kishita Y, Nyuzuki H, Moriyama Y, Mizuno Y, et al. A Comprehensive Genomic Analysis Reveals the Genetic Landscape of Mitochondrial Respiratory Chain Complex Deficiencies. Barsh GS, editor. PLOS Genet. 2016 Jan 7;12(1):e1005679.

80. Stenton SL, Piekutowska-Abramczuk D, Kulterer L, Kopajtich R, Claeys KG, Ciara E, et al. Expanding the clinical and genetic spectrum of FDXR deficiency by functional validation of variants of uncertain significance. Hum Mutat. 2021;42(3):310-9.

81. Dang VT, Kassahn KS, Marcos AE, Ragan MA. Identification of human haploinsufficient genes and their genomic proximity to segmental duplications. Eur J Hum Genet. 2008 Nov;16(11):1350-7.

82. Matharu N, Rattanasopha S, Tamura S, Maliskova L, Wang Y, Bernard A, et al. CRISPR-mediated activation of a promoter or enhancer rescues obesity caused by haploinsufficiency. Science. 2019 Jan 18;363(6424):eaau0629.

83. Heyne HO, Singh T, Stamberger H, Abou Jamra R, Caglayan H, Craiu D, et al. De novo variants in neurodevelopmental disorders with epilepsy. Nat Genet. 2018 Jul;50(7):1048-53.

84. Short PJ, McRae JF, Gallone G, Sifrim A, Won H, Geschwind DH, et al. De novo mutations in regulatory elements in neurodevelopmental disorders. Nature. 2018 Mar;555(7698):611-6.

85. Piskol R, Ramaswami G, Li JB. Reliable Identification of Genomic Variants from RNA-Seq Data. Am J Hum Genet. 2013 Oct;93(4):641-51.

86. GTEx Consortium. Genetic effects on gene expression across human tissues. Nature. 2017 
medRxiv preprint doi: https://doi.org/10.1101/2021.04.01.21254633; this version posted May 16, 2021. The copyright holder for this preprint

(which was not certified by peer review) is the author/funder, who has granted medRxiv a license to display the preprint in perpetuity.

It is made available under a CC-BY-NC-ND 4.0 International license .

Oct;550(7675):204-13.

87. Smit A, Hubley R, Green P. RepeatMasker Open [Internet]. 2013. Available from: http://www.repeatmasker.org

88. Simon MT, Eftekharian SS, Stover AE, Osborne AF, Braffman BH, Chang RC, et al. Novel mutations in the mitochondrial complex I assembly gene NDUFAF5 reveal heterogeneous phenotypes. Mol Genet Metab. 2019 Jan;126(1):53-63.

89. Nambot S, Gavrilov D, Thevenon J, Bruel AL, Bainbridge M, Rio M, et al. Further delineation of a rare recessive encephalomyopathy linked to mutations in GFER thanks to data sharing of whole exome sequencing data. Clin Genet. 2017 Aug;92(2):188-98.

90. Dyle MC, Kolakada D, Cortazar MA, Jagannathan S. How to get away with nonsense: Mechanisms and consequences of escape from nonsense-mediated RNA decay. WIREs RNA. 2020 Jan;11:e1560.

91. Teran NA, Nachun D, Eulalio T, Ferraro NM, Smail C, Rivas MA, et al. Nonsense-mediated decay is highly stable across individuals and tissues [Internet]. Genomics; 2021 Feb [cited 2021 Feb 8]. Available from: http://biorxiv.org/lookup/doi/10.1101/2021.02.03.429654

92. Li YI, Knowles DA, Humphrey J, Barbeira AN, Dickinson SP, Im HK, et al. Annotation-free quantification of RNA splicing using LeafCutter. Nat Genet. 2018 Jan;50(1):151-8.

93. Love MI, Huber W, Anders S. Moderated estimation of fold change and dispersion for RNA-seq data with DESeq2. Genome Biol. 2014 Dec;15(12):550.

94. Aicher JK, Jewell P, Vaquero-Garcia J, Barash Y, Bhoj EJ. Mapping RNA splicing variations in clinically accessible and nonaccessible tissues to facilitate Mendelian disease diagnosis using RNA-seq. Genet Med. 2020 Mar 30;22:1181-90.

95. Maddirevula S, Kuwahara H, Ewida N, Shamseldin HE, Patel N, Alzahrani F, et al. Analysis of transcript-deleterious variants in Mendelian disorders: implications for RNA-based diagnostics. Genome Biol. 2020 Dec;21(1):145.

96. Zappala Z, Montgomery SB. Non-Coding Loss-of-Function Variation in Human Genomes. Hum Hered. 2016;81(2):78-87.

97. D'Antonio M, Benaglio P, Jakubosky D, Greenwald WW, Matsui H, Donovan MKR, et al. Insights into the Mutational Burden of Human Induced Pluripotent Stem Cells from an Integrative Multi-Omics Approach. Cell Rep. 2018 Jul;24(4):883-94.

98. Mantere T, Kersten S, Hoischen A. Long-Read Sequencing Emerging in Medical Genetics. Front Genet. 2019;10:426.

99. Garrido-Martín D, Borsari B, Calvo M, Reverter F, Guigó R. Identification and analysis of splicing quantitative trait loci across multiple tissues in the human genome. Nat Commun. 2021 Dec;12(1):727.

100. Li H, Durbin R. Fast and accurate short read alignment with Burrows-Wheeler transform. Bioinformatics. 2009 Jul 15;25(14):1754-60.

101. Li H, Handsaker B, Wysoker A, Fennell T, Ruan J, Homer N, et al. The Sequence Alignment/Map format and SAMtools. Bioinformatics. 2009 Aug 15;25(16):2078-9.

102. Van der Auwera GA, Carneiro MO, Hartl C, Poplin R, del Angel G, Levy-Moonshine A, et al. From FastQ Data to High-Confidence Variant Calls: The Genome Analysis Toolkit Best Practices Pipeline. In: Current Protocols in Bioinformatics. Hoboken, NJ, USA: John Wiley \& Sons, Inc.; 2013. p. 11.10.1-11.10.33. 
medRxiv preprint doi: https://doi.org/10.1101/2021.04.01.21254633; this version posted May 16, 2021. The copyright holder for this preprint

(which was not certified by peer review) is the author/funder, who has granted medRxiv a license to display the preprint in perpetuity.

It is made available under a CC-BY-NC-ND 4.0 International license .

103. Bolger AM, Lohse M, Usadel B. Trimmomatic: a flexible trimmer for Illumina sequence data. Bioinformatics. 2014 Aug 1;30(15):2114-20.

104. The 1000 Genomes Project Consortium. A global reference for human genetic variation. Nature. 2015 Oct;526(7571):68-74.

105. Karczewski KJ, Francioli LC, Tiao G, Cummings BB, Alföldi J, Wang Q, et al. The mutational constraint spectrum quantified from variation in 141,456 humans. Nature. 2020 May;581(7809):434-43.

106. Obenchain V, Shepherd L. ensemblVEP: R Interface to Ensembl Variant Effect Predictor. 2020.

107. Zerbino DR, Achuthan P, Akanni W, Amode MR, Barrell D, Bhai J, et al. Ensembl 2018. Nucleic Acids Res. 2018 Jan 4;46(D1):D754-61.

108. den Dunnen JT, Dalgleish R, Maglott DR, Hart RK, Greenblatt MS, McGowan-Jordan J, et al. HGVS Recommendations for the Description of Sequence Variants: 2016 Update. Hum Mutat. 2016 Jun;37(6):564-9.

109. Lawrence M, Huber W, Pagès H, Aboyoun P, Carlson M, Gentleman R, et al. Software for Computing and Annotating Genomic Ranges. Prlic A, editor. PLoS Comput Biol. 2013 Aug 8;9(8):e1003118.

110. Dobin A, Davis CA, Schlesinger F, Drenkow J, Zaleski C, Jha S, et al. STAR: ultrafast universal RNA-seq aligner. Bioinformatics. 2013 Jan;29(1):15-21.

111. Ewels P, Magnusson M, Lundin S, Käller M. MultiQC: summarize analysis results for multiple tools and samples in a single report. Bioinformatics. 2016 Oct 1;32(19):3047-8.

112. Frankish A, Diekhans M, Ferreira A-M, Johnson R, Jungreis I, Loveland J, et al. GENCODE reference annotation for the human and mouse genomes. Nucleic Acids Res. 2019 Jan 8;47(D1):D766-73.

113. Robinson JT, Thorvaldsdóttir H, Winckler W, Guttman M, Lander ES, Getz G, et al. Integrative genomics viewer. Nat Biotechnol. 2011;29(1):3.

114. Castel SE, Levy-Moonshine A, Mohammadi P, Banks E, Lappalainen T. Tools and best practices for data processing in allelic expression analysis. Genome Biol. 2015 Dec;16(1):195.

115. Baran Y, Subramaniam M, Biton A, Tukiainen T, Tsang EK, Rivas MA, et al. The landscape of genomic imprinting across diverse adult human tissues. Genome Res. 2015 Jul;25(7):927-36. 